\title{
Uptake and metabolic effects of insulin mimetic oxovanadium compounds in human erythrocytes
}

\author{
Teresa C. Delgado ${ }^{\mathrm{a}}$, A. Isabel Tomaz ${ }^{\mathrm{a}, \mathrm{b}}$, Isabel Correia ${ }^{\mathrm{b}}$, João Costa Pessoa ${ }^{\mathrm{b}}$, \\ John G. Jones ${ }^{\text {a }}$, Carlos F.G.C. Geraldes ${ }^{\text {a }}$, M. Margarida C.A. Castro ${ }^{\text {a,* }}$ \\ a Department of Biochemistry, Center of NMR Spectroscopy and Center for Neurosciences and Cell Biology, University of Coimbra, \\ P.O. Box 3126, 3001-401 Coimbra, Portugal \\ ${ }^{\mathrm{b}}$ Centro de Química Estrutural, Instituto Superior Técnico, Av. Rovisco Pais, 1049-001 Lisboa, Portugal
}

Received 16 June 2005; received in revised form 1 August 2005; accepted 26 August 2005

Available online 14 October 2005

\begin{abstract}
The uptake of the oxidation products of two oxovanadium(IV) compounds, $\left[N, N^{\prime}\right.$-ethylenebis(pyridoxylaminato) $]$ oxovanadium(IV), $\mathrm{V}^{\mathrm{IV}} \mathrm{O}\left(\mathrm{Rpyr}_{2} \mathrm{en}\right)$, and bis-[3-hydroxy-1,2-dimethyl-4-pyridinonato]oxovanadium(IV), $\mathrm{V}^{\mathrm{IV}} \mathrm{O}(\mathrm{dmpp})_{2}$, by human erythrocytes was studied using ${ }^{51} \mathrm{~V}$ and ${ }^{1} \mathrm{H}$ NMR and EPR spectroscopy. $\mathrm{V}^{\mathrm{IV}} \mathrm{O}\left(\mathrm{Rpyr}_{2} \mathrm{en}\right)$ in aerobic aqueous solution is oxidized to its $\mathrm{V}^{\mathrm{V}}$ counterpart and the neutral form slowly enters the cells by passive diffusion. In aerobic conditions, $\mathrm{V}^{\mathrm{IV}} \mathrm{O}(\mathrm{dmpp})_{2}$ originates $\mathrm{V}^{\mathrm{V}}$ complexes of $1: 1$ and 1:2 stoichiometry. The neutral 1:1 species is taken up by erythrocytes through passive diffusion in a temperature-dependent process; its depletion from the extracellular medium promotes the dissociation of the negatively charged 1:2 species, and the protonation of the negatively charged 1:1 species. The identity of these complexes is not maintained inside the cells, and the intracellular EPR spectra suggest $\mathrm{N}_{2} \mathrm{O}_{2}$ or $\mathrm{NO}_{3}$ intracellular coordinating environments. The oxidative stress induced by the oxovanadium compounds in erythrocytes was not significant at $1 \mathrm{mM}$ concentration, but was increased by both vanadate and oxidized $\mathrm{V}^{\mathrm{IV}} \mathrm{O}(\mathrm{dmpp})_{2}$ at $5 \mathrm{mM}$. Only $1 \mathrm{mM}$ oxidized $\mathrm{V}^{\mathrm{IV}} \mathrm{O}(\mathrm{dmpp})_{2}$ significantly stimulated erythrocytes glucose intake $(0.75 \pm 0.13$ against $0.37 \pm 0.17 \mathrm{mM} / \mathrm{h}$ found for the control, $p<0.05)$.
\end{abstract}

(C) 2005 Elsevier Inc. All rights reserved.

Keywords: Oxovanadium compounds; Human erythrocytes; Vanadium uptake; NMR and EPR spectroscopy

\section{Introduction}

Many vanadium salts and their complexes have shown insulin mimetic pharmacological properties, including stimulation of glucose transport into cells and its oxidation via glycolysis, glycogen synthesis and lipogenesis, as well as inhibition of gluconeogenesis and glycogenolysis [1-4]. These anti-diabetic properties of vanadium compounds, which have been demonstrated by in vitro [5-10], in vivo $[11,12]$ and clinical studies $[2,13,14]$, have attracted much interest as potential therapeutic agents for Diabetes mellitus [11,15-18]. They can be administered orally and have

\footnotetext{
${ }^{*}$ Corresponding author. Tel.: +351 239 853609; fax: +351 239853607.

E-mail address: gcastro@ci.uc.pt (M. Margarida C.A. Castro).
}

been shown to promote glucose uptake in animal models of type 1 and type 2 diabetes [13,19]. However, toxicity, although lower in vanadium complexes than for their salts, is still a major drawback, in particular for $\mathrm{V}^{\mathrm{IV}}$ compounds $[13,14,18]$.

Current research is underway to design new and more effective insulin mimetic vanadium compounds with lower toxicity. Key goals are to identify the active vanadium species and to understand their mechanism of action at the cellular and molecular levels. Vanadate and several $\mathrm{V}^{\mathrm{V}}$ compounds inhibit the activity of several enzymes $[2,20]$ in particular protein tyrosine phosphatases (PTPases) $[9,10,21-24]$, increasing the phosphotyrosil content of key proteins of the insulin signaling cascade [6]. Adequate ligand design can efficiently increase the stability of the 
vanadium complex in the stomach and its absorption through the gastrointestinal (GI) tract, thereby reducing the effective pharmacological dose [25]. Studies with a variety of $\mathrm{V}^{\mathrm{V}}$ and $\mathrm{V}^{\mathrm{IV}}$ compounds with OO, ON, OS, NS and ONS ligand donor sets have shown the insulin mimetic activity of some of them as well as their low toxicity [2631]. The bioavailability of vanadium complexes can also be improved by increasing their GI absorption through their delivery in an intact form using, e.g., enteric-coating capsulation [32-34].

In body fluids, vanadium is present in the +5 oxidation state as monovanadate $\left(\mathrm{H}_{2} \mathrm{VO}_{4}^{-}\right)$, which is isostructural with phosphate [35], and can be transported into the cells through the anion channel of plasma membranes [36,37]. Under the reducing conditions of the intracellular environment, where glutathione and reductase enzymes are present, monovanadate is non-enzymatically reduced to vanadyl $\left(\mathrm{V}^{\mathrm{IV}} \mathrm{O}^{2+}\right)$, probably by cytoplasmatic glutathione $[38-40] . \mathrm{V}^{\mathrm{IV}} \mathrm{O}^{2+}$ also forms relatively stable adducts with proteins such as hemoglobin [37,39,40]. Glutathione was initially proposed as an efficient $\mathrm{V}^{\mathrm{IV}} \mathrm{O}^{2+}$ intracellular binder [41,42], but this activity was found to be low in biological media $[43,44]$. The intracellular ligand environment of $\mathrm{V}^{\mathrm{IV}}$ species has been investigated by EPR and electron spin echo envelope modulation (ESEEM) spectroscopy through in vitro $[45,46]$ and in vivo [47-49] studies.

In this paper, we report a study of the uptake, intracellular reduction and binding of the aerobic oxidation products of two oxovanadium(IV) compounds in human erythrocytes, using ${ }^{51} \mathrm{~V}$ and ${ }^{1} \mathrm{H}$ NMR and EPR spectroscopy. These compounds are the complexes $\left[N, N^{\prime}\right.$-ethylenebis(pyridoxylaminato)]oxovanadium(IV), $\mathrm{V}^{\mathrm{IV}} \mathrm{O}\left(\mathrm{Rpyr}_{2} \mathrm{en}\right)$ and bis-[3-hydroxy-1,2-dimethyl-4-pyridinonato]oxovana$\operatorname{dium}(\mathrm{IV}), \mathrm{V}^{\mathrm{IV}} \mathrm{O}(\mathrm{dmpp})_{2}$ (see Fig. 1), which have previously been synthesized and their structures, as well as those of the corresponding $\mathrm{V}^{\mathrm{V}}$ analogues, were characterized in the solid state and in solution [50-54]. They have also been shown by in vitro studies to be promising insulin mimetic candidates $[18,54]$.

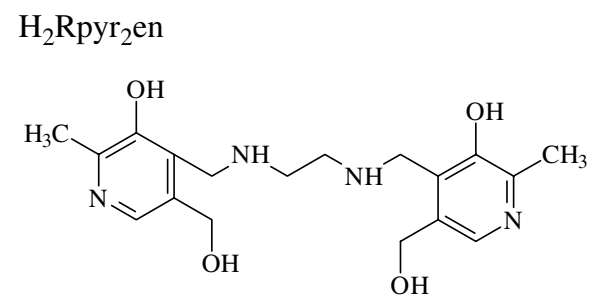

Hdmpp<smiles>Cc1c(O)c(=O)ccn1C</smiles>

Fig. 1. Schematic representation of the ligands $N, N^{\prime}$-ethylenebis(pyridoxylamine $) \quad\left(\mathrm{H}_{2} \mathrm{Rpyr}_{2} \mathrm{en}\right)$ and 3-hydroxy-1,2-dimethyl-4-pyridinone (Hdmpp).

\section{Experimental}

\subsection{General materials}

All reagents and solvents were of the commercially available highest grade and used without further purification. $\mathrm{NaCl}, \mathrm{NaH}_{2} \mathrm{PO}_{4}, \mathrm{CaCl}_{2} \cdot \mathrm{H}_{2} \mathrm{O}$, sodium vanadate $\left(\mathrm{Na}_{3} \mathrm{VO}_{4}\right)$, vanadyl sulfate $\left(\mathrm{VOSO}_{4} \cdot \mathrm{H}_{2} \mathrm{O}\right), 4,4^{\prime}$-diisothiocyanatostilbene- $2,2^{\prime}$-disulfonic acid disodium salt (DIDS) and methylene blue were obtained from Aldrich Chem. Co., and glucose, sodium citrate, citric acid, $N$-[2-hydroxyethyl]piperazine- $N^{\prime}$-[2-ethanesulfonic acid] (HEPES) and $\mathrm{KCl}$ from Merck. $\mathrm{D}_{2} \mathrm{O}\left(99.9 \%\right.$ atom D) and $\left[2{ }^{13} \mathrm{C}\right] \mathrm{D}$-glucose $(99 \%)$ were purchased from Cambridge Isotope Laboratories.

The vanadium(IV) compounds $\mathrm{V}^{\mathrm{IV}} \mathrm{O}\left(\mathrm{Rpyr}_{2} \mathrm{en}\right)$ and $\mathrm{V}^{\mathrm{IV}} \mathrm{O}(\mathrm{dmpp})_{2}$ were synthesized as previously described [50-53]. All experiments with these $\mathrm{V}^{\mathrm{IV}} \mathrm{O}$-compounds were carried out in aqueous solution and under aerobic conditions.

$10 \mathrm{mM}$ solutions of these $\mathrm{V}^{\mathrm{IV}} \mathrm{O}$-compounds were prepared in PBS (140 mM NaCl and $5 \mathrm{mM} \mathrm{NaH} \mathrm{PO}_{4} ; \mathrm{pH}$ 7.40-7.45) or HEPES/saline buffer (25.0 mM HEPES, $120.0 \mathrm{mM} \mathrm{NaCl}, 5.4 \mathrm{mM} \mathrm{KCl}, 1.8 \mathrm{mM} \mathrm{CaCl} 2$ and $1.0 \mathrm{mM} \mathrm{NaH} \mathrm{PO}_{4} ; \mathrm{pH} \mathrm{7.40-7.45)}$ and left standing in aerobic conditions for at least $12 \mathrm{~h}$. The full oxidation of $\mathrm{V}^{\mathrm{IV}}$ to $\mathrm{V}^{\mathrm{V}}$ species was confirmed by the absence of an EPR signal and the observation of the expected ${ }^{51} \mathrm{~V}$ NMR signals.

\subsection{Blood processing}

Blood was obtained following informed consent from healthy adult volunteers and was drawn by venipuncture into tubes containing 'acid citric dextrose' as anticoagulant. Blood samples were immediately centrifuged for $10 \mathrm{~min}$ at $3000 \mathrm{rpm}$ (1300g in a Heraeus Sepatech Labofuge Ae) and the plasma and buffy coat were removed and discarded. The erythrocytes were then resuspended in an equal volume of the adequate buffer, centrifuged as before and suspended again in fresh buffer. This process was repeated twice.

\subsection{Preparation of erythrocyte lysates}

After carrying out all the experiments, the erythrocyte suspensions were centrifuged to separate the erythrocytes from the supernatant and the supernatant discarded. The erythrocytes were washed twice with the PBS buffer, which was removed by centrifugation, frozen without the supernatant and kept at $-20^{\circ} \mathrm{C}$. When the samples were defrosted, lysis occurred immediately. To obtain homogenous erythrocyte lysates for EPR analysis, three freeze thaw cycles were carried out.

\subsection{Uptake of vanadium compounds}

The isolated erythrocytes were resuspended at a hematocrit of $45-50 \%$ in PBS containing $11 \mathrm{mM}$ glucose with or 
without (control) $1 \mathrm{mM}$ DIDS and were incubated at 25 or $37^{\circ} \mathrm{C}$. Ten minutes later, solutions of $10 \mathrm{mM}$ vanadate or $10 \mathrm{mM} \mathrm{V} \mathrm{V}^{\mathrm{IV}} \mathrm{O}$-compounds oxidation products were added to the cell suspensions to obtain a final concentration of $1 \mathrm{mM}$ in the extracellular medium. Aliquots were taken at different time points and centrifuged for $10 \mathrm{~min}$ at $3000 \mathrm{rpm}$ to separate the supernatant from erythrocytes. The extracellular medium of each aliquot was analyzed by ${ }^{51} \mathrm{~V}$ NMR and the erythrocyte lysates were studied by EPR. In the experiments involving $\mathrm{V}^{\mathrm{IV}} \mathrm{O}(\mathrm{dmpp})_{2}, 100 \mu \mathrm{l}$ of the supernatant of each sample were lyophilized and resuspended in $600 \mu 1 \mathrm{D}_{2} \mathrm{O}$ for further ${ }^{1} \mathrm{H}$ NMR analysis. During all experiments, the $\mathrm{pH}$ was periodically measured to check if it deviated substantially from the 7.4 starting value.

\section{5. ${ }^{51} V$ NMR spectroscopy}

${ }^{51} \mathrm{~V}$ NMR spectra of the extracellular medium of the erythrocyte suspensions were obtained on a Varian Unity 500 Spectrometer equipped with a $5-\mathrm{mm}$ broadband "switchable" probe with z-gradient (Varian, Palo Alto, CA, USA) operating at $131.399 \mathrm{MHz}$ and at $25.0 \pm 0.5^{\circ} \mathrm{C}$. A single-pulse sequence with standard acquisition parameters for ${ }^{51} \mathrm{~V}$ was used. The spectral parameters were as follows: sweep width $18727.6 \mathrm{~Hz}$, pulse angle $45^{\circ}$ (pulse width $25 \mu \mathrm{s}$ ), acquisition time $0.501 \mathrm{~s}$, number of points $18 \mathrm{k}$, relaxation delay $0.200 \mathrm{~s}$, line broadening $50 \mathrm{~Hz}$, zero filled to $30 \mathrm{k}$. A sodium orthovanadate solution of known concentration $(0.5$ or $1.0 \mathrm{mM}), \mathrm{pH} 12$ in a capillary (length: $75.00 \pm 1.00 \mathrm{~mm}$, inner circle diameter: $1.15 \pm 0.05 \mathrm{~mm}$, outer circle diameter: $1.55 \pm 0.05 \mathrm{~mm}$ ) inside the NMR tube was used as an external reference for quantitative analysis. The signals were integrated using the NUTS PC-based NMR spectral analysis program (Acorn NMR Inc., Fremont CA, USA).

\section{6. ${ }^{1} H$ NMR spectroscopy}

${ }^{1} \mathrm{H}$ NMR spectra of the lyophilized extracellular medium of erythrocyte samples were obtained on the same instrument operating at $499.824 \mathrm{MHz}$ and at $25.0 \pm 0.5^{\circ} \mathrm{C}$. A single pulse sequence with standard acquisition parameters for ${ }^{1} \mathrm{H}$ with pre-saturation to suppress the water signal was used. Spectral parameters were as follows: sweep width $8000 \mathrm{~Hz}$, pulse angle $51^{\circ}$ (pulse width $11 \mu \mathrm{s}$ ), acquisition time $3.004 \mathrm{~s}$, number of points $24 \mathrm{k}$, relaxation delay $1.5 \mathrm{~s}$, no line broadening, zero filled to $48 \mathrm{k}$. The integrals of the signals were also determined using the NUTS PC-based NMR spectral analysis program.

\subsection{EPR spectroscopy}

EPR spectra were recorded at $77 \mathrm{~K}$ on a Bruker ESP 300E Spectrometer coupled to a Bruker ER 041 XK Xband frequency meter $(9.45 \mathrm{GHz})$. The samples (erythrocyte lysates, aqueous solutions of $\mathrm{V}^{\mathrm{IV}} \mathrm{O}$ complexes and
$\mathrm{VOSO}_{4}$ ) were previously frozen in liquid nitrogen. The settings used for all experiments were: microwave power: $2 \mathrm{~mW}$; modulation amplitude: $3.6 \mathrm{G}$; time constant: $2.56 \mathrm{~ms}$; conversion time $40.96 \mathrm{~ms}$; sweep field: $3400 \pm 1000 \mathrm{G}$. Spectral intensities were measured at the $m_{\mathrm{I}}=-1 / 2_{\perp}$ line. Spectra were simulated with a dedicated computer program [55]. In some cases (spectra with more than two species), hyperfine coupling constants and $g$-values were estimated using an iterative procedure based on equations proposed in the literature [56] and later corrected [57]. An empirical relationship [56] has been proposed to predict the $A_{\|}$from individual contributions of each donor group, $A_{\|}=\sum_{i=1}^{4} A_{\|_{i}}$. A similar additivity rule may be applied to $g_{\|}$. The $A_{\|}$and $g_{\|}$parameters show good sensitivity to the identity of the in-plane donor groups. This relationship is useful to estimate $A_{\|}$values within $\pm 3 \times 10^{-4} \mathrm{~cm}^{-1}$, and it can be used to establish the most probable binding mode for the $\mathrm{V}^{\mathrm{IV}} \mathrm{O}$ moiety [56-61].

\subsection{Oxidative stress effects}

The erythrocytes were resuspended at $\sim 10 \%$ hematocrit in HEPES/saline buffer solution (for $60 \mathrm{~min}$ ) at $37^{\circ} \mathrm{C}$ to wash out endogenous glucose and lactate. Then, the erythrocyte samples were centrifuged and resuspended at a hematocrit of $45-50 \%$ in HEPES/saline buffer containing $11 \mathrm{mM}\left[2{ }^{13} \mathrm{C}\right] \mathrm{D}$-glucose. HEPES/saline buffer solutions of methylene blue, vanadate, $\mathrm{V}^{\mathrm{IV}} \mathrm{O}\left(\mathrm{Rpyr}_{2} \mathrm{en}\right)$ and $\mathrm{V}^{\mathrm{IV}} \mathrm{O}(\mathrm{dmpp})_{2}$ oxidation products were added to the erythrocyte suspension to test their oxidative toxicity. Their effect on the pentose phosphate pathway (PP) flux was compared with that of methylene blue, used as a standard stimulating agent of PP flux [62]. Erythrocyte samples were incubated at $37^{\circ} \mathrm{C}$ for $8 \mathrm{~h}$ and then centrifuged for $10 \mathrm{~min}$ at $3000 \mathrm{rpm}$. The supernatant of each sample $(100 \mu \mathrm{l})$ was lyophilized and resuspended in $600 \mu \mathrm{D}_{2} \mathrm{O}$ for ${ }^{1} \mathrm{H}$ NMR analysis.

${ }^{1} \mathrm{H}$ NMR spectra of the lyophilized extracellular medium of all erythrocyte samples were recorded as mentioned above at $25.0 \pm 0.5^{\circ} \mathrm{C}$. The ${ }^{13} \mathrm{C}-{ }^{1} \mathrm{H}$ decoupling of the carbon 1 signal of lactate was achieved with low power singlefrequency irradiation continuously applied. Deconvolution and quantification of the ${ }^{1} \mathrm{H}$ signals of the methyl group of ${ }^{13} \mathrm{C}$-labeled lactate was carried out with the curve-fitting routine supplied with the NUTS PC-based NMR spectral analysis program. The fraction of glucose-6-phosphate consumed by the pentose pathway relative to the total (glycolysis + pentose pathway) was calculated from the lactate ${ }^{1} \mathrm{H}$ methyl signal as already described [62].

\subsection{Glucose intake assay}

To test the glucose intake by erythrocytes, the cell suspensions were prepared as described in the previous section using $11 \mathrm{mM}$ of non-labeled glucose instead of $\left[2-{ }^{13} \mathrm{C}\right] \mathrm{D}-$ glucose. To evaluate the glucose consumption rates, HEPES/saline buffer solutions of methylene blue, vanadate 
or the two $\mathrm{V}^{\mathrm{IV}} \mathrm{O}$-compounds under study were added to the cell suspension to give final concentrations of $6.7 \mu \mathrm{M}$ for methylene blue, and $1 \mathrm{mM}$ for the other compounds. All erythrocyte samples were incubated at $37{ }^{\circ} \mathrm{C}$ for $8 \mathrm{~h}$ and aliquots were taken every hour. These aliquots were then centrifuged for $10 \mathrm{~min}$ at $3000 \mathrm{rpm}$ to separate the erythrocytes from the extracellular medium, which was boiled to precipitate the proteins. After centrifugation, the pellet was discarded and the glucose concentration in the supernatant was determined by a spectrophotometric biochemical assay from Boehringer Mannheim/R-Biopharm (Roche) based on the hexokinase method [63].

\subsection{Data analysis}

Data are expressed as mean \pm SEM and $p<0.05$ was considered significant. Statistical significance was determined by using the Student's $t$ test and the number of replicates is indicated in each figure.

\section{Results and discussion}

\subsection{Uptake of vanadium compounds by erythrocytes}

The uptake by human erythrocytes of the $\mathrm{V}^{\mathrm{V}}$ oxidation products of the oxovanadium complexes $\mathrm{V}^{\mathrm{IV}} \mathrm{O}\left(\mathrm{Rpyr}_{2}\right.$ en $)$ and $\mathrm{V}^{\mathrm{IV}} \mathrm{O}(\mathrm{dmpp})_{2}$ was investigated using NMR and EPR spectroscopy. These $\mathrm{V}^{\mathrm{V}}$ species present in the medium are reduced to $\mathrm{V}^{\mathrm{IV}}$ species inside the cells, as shown by their intracellular EPR signals (see below). The time evolution of the concentration of the $\mathrm{V}^{\mathrm{V}}$ species in the extracellular medium and of the $\mathrm{V}^{\mathrm{IV}}$ species inside the cells was followed by ${ }^{51} \mathrm{~V}$ NMR and EPR spectroscopy, respectively.

Human erythrocytes were chosen as our initial cell model for several reasons: (a) they are among the first cell systems to be affected by the vanadium compounds after they are absorbed in the GI tract; (b) have a simple morphology and physiology, together with well-known membrane transport systems; (c) have a well-defined metabolic mechanism for the maintenance of reduced glutathione levels during oxidative stress. Thus, erythrocytes allow both the study of cell uptake of vanadium compounds and their effects on intracellular metabolism and redox state.

\subsubsection{NMR studies}

Figs. 2A, 3 and 4A show the time dependence of the ${ }^{51} \mathrm{~V}$ NMR spectra obtained from the extracellular medium of erythrocyte suspensions incubated with vanadate $\left(25^{\circ} \mathrm{C}\right.$, $1 \mathrm{mM})$, oxidized $\mathrm{V}^{\mathrm{IV}} \mathrm{O}\left(\mathrm{Rpyr}_{2}\right.$ en $)\left(37^{\circ} \mathrm{C}, 1 \mathrm{mM}\right)$ and oxidized $\mathrm{V}^{\mathrm{IV}} \mathrm{O}(\mathrm{dmpp})_{2}\left(25\right.$ and $\left.37^{\circ} \mathrm{C}, 1 \mathrm{mM}\right)$, respectively.

At the physiological conditions used, the ${ }^{51} \mathrm{~V}$ NMR spectra of the medium with added vanadate contain three peaks at $-562,-574$ and $-579 \mathrm{ppm}$, corresponding to mono- $\left(\mathrm{V}_{1}\right)$, di- $\left(\mathrm{V}_{2}\right)$, and tetravanadate $\left(\mathrm{V}_{4}\right)$, respectively, in slow exchange on the NMR timescale (Fig. 2A). These species are in a dynamic equilibrium with rate constants for the forward and reverse reactions of the order of milli-
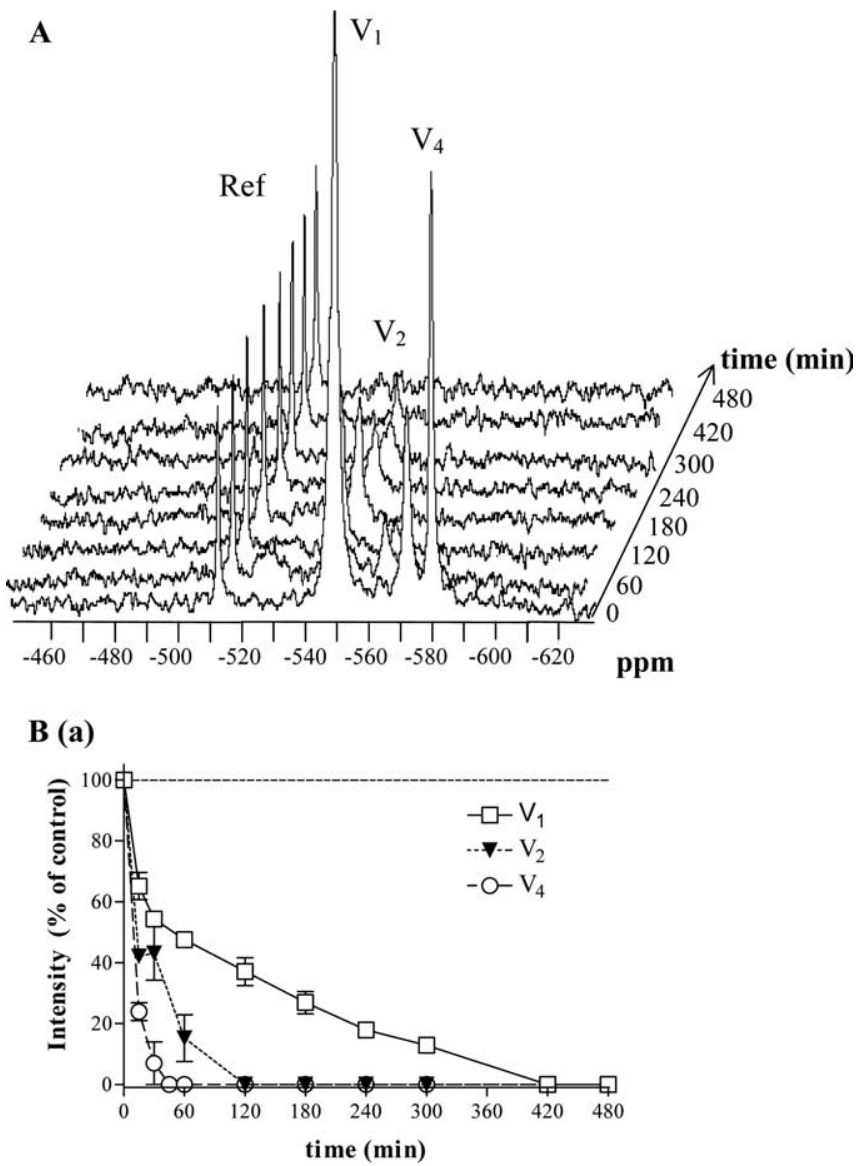

(b)

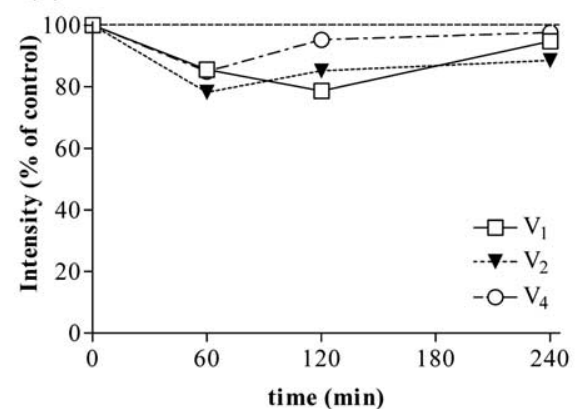

Fig. 2. (A) ${ }^{51} \mathrm{~V}$ NMR spectra of the extracellular medium of human erythrocyte suspensions $(\mathrm{Ht}=50 \%)$ incubated with $1 \mathrm{mM}$ vanadate, at $25^{\circ} \mathrm{C}$, as a function of time (Ref is the external reference, $\mathrm{V}_{1}, \mathrm{~V}_{2}$ and $\mathrm{V}_{4}$ are mono-, di- and tetravanadate, respectively); (B) Graphical representation of the intensity of the ${ }^{51} \mathrm{~V}$ NMR signals (percentage of the control considered $100 \%$ ) as a function of time for each of the $\mathrm{V}^{\mathrm{V}}$ species present in the extracellular medium of human erythrocyte suspensions: (a) incubated with $1 \mathrm{mM}$ vanadate at $25^{\circ} \mathrm{C}$ and (b) previously incubated with $1 \mathrm{mM}$ of DIDS, the anion channel blocker, and then with $1 \mathrm{mM}$ vanadate, at $25^{\circ} \mathrm{C} . \mathrm{V}_{1}(-\square-), \mathrm{V}_{2}(\cdots \nabla \cdots)$ and $\mathrm{V}_{4}(-\mathrm{O}-)$. Values are given as means $\pm \operatorname{SEM}(n=3)$.

seconds [64]. The ${ }^{51} \mathrm{~V}$ NMR signal intensities of the three species decrease with time, faster for $\mathrm{V}_{4}$ than for $\mathrm{V}_{2}$, being slower for $\mathrm{V}_{1}$, as shown by the signal integrals of the $\mathrm{V}_{i}$ species $(i=1,2,4)($ Fig. $2 \mathrm{~B}(\mathrm{a}))$. It is likely that vanadate is transported across the erythrocyte membrane only as the monomer, as the properties of the monovanadate anion 

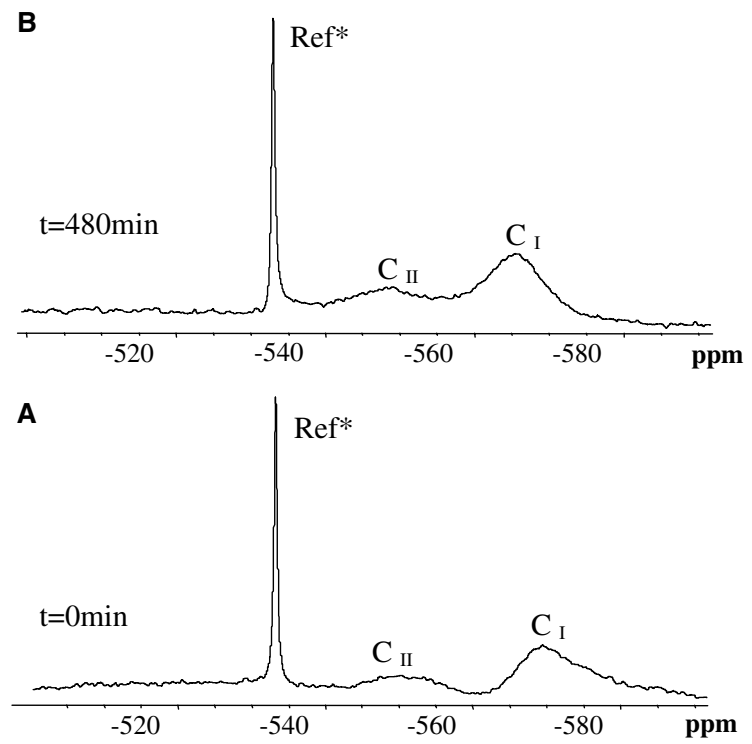

Fig. $3 .{ }^{51} \mathrm{~V}$ NMR spectra of the extracellular medium of human erythrocyte suspensions $(\mathrm{Ht}=50 \%)$ incubated with $1 \mathrm{mM}$ oxidized $\mathrm{V}^{\mathrm{IV}} \mathrm{O}\left(\mathrm{Rpyr}_{2} \mathrm{en}\right)$, at $37^{\circ} \mathrm{C}$. (A) $t=0 \mathrm{~min}$ and (B) $t=480 \mathrm{~min}\left(\mathrm{C}_{\mathrm{I}}\right.$ and $\mathrm{C}_{\mathrm{II}}$ are, the $\alpha$-cis and $\beta$-cis isomers of $\left[\mathrm{V}^{\mathrm{V}} \mathrm{O}_{2}\left(\mathrm{HRpyr}_{2} \mathrm{en}\right)\right]$, respectively, and Ref* is the external reference).
$\left(\mathrm{H}_{2} \mathrm{VO}_{4}^{-}\right.$in these conditions) are closer to those of $\mathrm{H}_{2} \mathrm{PO}_{4}^{-}$, one of the natural anions transported by the anion channel, Band 3 protein $[37,65]$. Therefore, the fast decrease of the NMR signals corresponding to $V_{2}$ and $V_{4}$ indicates their decomposition into $V_{1}$ to reestablish the equilibrium as $\mathrm{V}_{1}$ enters the erythrocytes.

The entry of $V_{1}$ in erythrocytes through the anion channel was confirmed by the absence of changes in the intensity of the ${ }^{51} \mathrm{~V}$ NMR signals of the mono and polynuclear $\mathrm{V}^{\mathrm{V}}$ species with time in the extracellular medium for erythrocyte suspensions incubated with $1 \mathrm{mM}$ vanadate and the specific anion channel blocker DIDS (Fig. 2B(b)). These results are in agreement with data described in the literature using ${ }^{48} \mathrm{~V}$ radioactive isotopes and EPR [36,37,66,67].

A semilogarithmic plot of the time decay of the total integral of the three ${ }^{51} \mathrm{~V}$ NMR signals (which is a measure of the extracellular $\mathrm{V}^{\mathrm{V}}$, as intracellular $\mathrm{V}^{\mathrm{V}}$ is NMR invisible [37]) shows a biphasic kinetics of vanadate uptake, with a fast initial phase $\left(t_{1 / 2} \sim 6 \mathrm{~min}\right)$ when $\mathrm{V}_{1}$ enters the erythrocytes, followed by a slower phase $\left(t_{1 / 2} \sim 118 \mathrm{~min}\right)$ (data not shown). These results are similar to those previously reported, using ${ }^{48} \mathrm{~V}$ radioisotopes and EPR, where it is

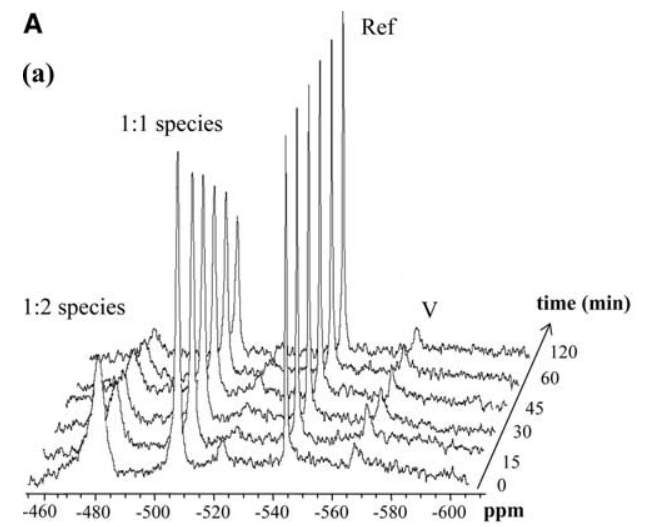

(b)

B

(a)

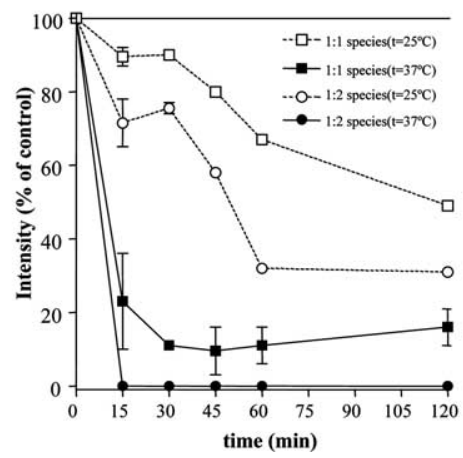

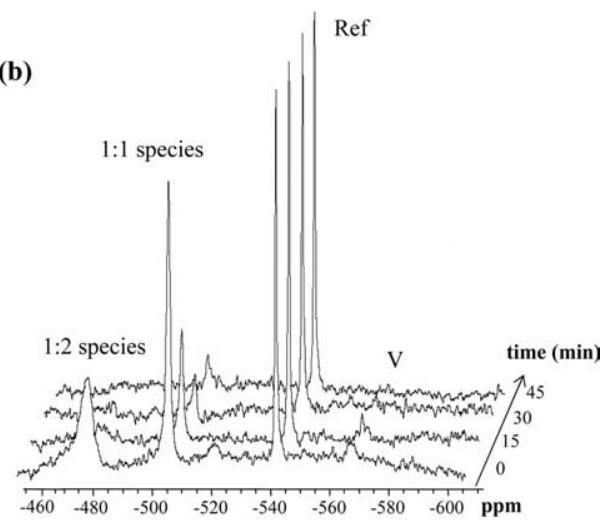

(b)



Fig. 4. (A) ${ }^{51} \mathrm{~V}$ NMR spectra of the extracellular medium of human erythrocyte suspensions $(\mathrm{Ht}=50 \%)$ incubated with $1 \mathrm{mM}$ oxidized $\mathrm{V}^{\mathrm{IV}} \mathrm{O}(\mathrm{dmpp})_{2}$ as a function of time at: (a) $25^{\circ} \mathrm{C}$ and (b) $37^{\circ} \mathrm{C}$. The $1: 2$ species is $\mathrm{V}^{\mathrm{V}} \mathrm{O}_{2} \mathrm{~L}_{2}$; the $1: 1$ species is $\mathrm{V}^{\mathrm{V}} \mathrm{O}_{2} \mathrm{~L}(\mathrm{~L}=\mathrm{dmpp}$ ), $\mathrm{V}$ is free vanadate and Ref is the external reference; (B) Graphical representation of the intensity of the ${ }^{51} \mathrm{~V}$ NMR signals (percentage of control considered $100 \%$ ) as a function of time of: (a) $\mathrm{V}^{\mathrm{V}}$ species present in the extracellular medium of human erythrocyte suspensions incubated with $1 \mathrm{mM}$ of oxidized $\mathrm{V}^{\mathrm{IV}} \mathrm{O}\left(\mathrm{dmpp}_{2}\right.$ at $t=25$ and $37^{\circ} \mathrm{C} \mathrm{V}^{\mathrm{V}} \mathrm{O}_{2} \mathrm{~L}$ at $25{ }^{\circ} \mathrm{C}(\cdots \square \cdots)$ and at $37{ }^{\circ} \mathrm{C}(-\square-), \mathrm{V}^{\mathrm{V}} \mathrm{O}_{2} \mathrm{~L}_{2}$ at $25^{\circ} \mathrm{C}(-\mathrm{O}-)$ and $37{ }^{\circ} \mathrm{C}\left(-\mathbf{O}_{-}\right)$; (b) the negatively charged $1: 2$ species $\left[\mathrm{V}^{\mathrm{V}} \mathrm{O}_{2} \mathrm{~L}_{2}\right]^{-}$present in the extracellular medium of human erythrocytes previously incubated with $1 \mathrm{mM}$ DIDS, the anion channel blocker, and then $1 \mathrm{mM}$ of oxidized $\mathrm{V}^{\mathrm{IV}} \mathrm{O}(\mathrm{dmpp})_{2}$ $(\mathrm{L}=\mathrm{dmpp})$, at $t=25^{\circ} \mathrm{C}$. Values are given as means $\pm \operatorname{SEM}(n=3)$. 
suggested that the slower phase of vanadate transport might be due to the reduction of $\mathrm{V}^{\mathrm{V}}$ to $\mathrm{V}^{\mathrm{IV}}$ within the cells, with intracellular retention of $\mathrm{V}^{\mathrm{IV}}[36,67]$. The differences in $t_{1 / 2}$ values obtained in this work relative to those described in the literature are probably due to the different experimental conditions used, e.g. the composition of the media, temperature, hematocrit and concentration of vanadate in the extracellular medium [67].

Dissolution of the $\mathrm{V}^{\mathrm{IV}} \mathrm{O}\left(\mathrm{Rpyr}_{2} \mathrm{en}\right)$ complex in the aqueous buffer solution used, under aerobic conditions and at physiological $\mathrm{pH}$ ( $\mathrm{pH}$ 7.45), leads to complete oxidation to the corresponding $\mathrm{V}^{\mathrm{V}}$ complex, $\mathrm{V}^{\mathrm{V}} \mathrm{O}_{2}\left(\mathrm{HRpyr}_{2} \mathrm{en}\right)$ after $12 \mathrm{~h}$, as checked by EPR. This complex has two isomers with 1:1 stoichiometry, the $\alpha$-cis (or cis-phenolate, $\mathrm{C}_{\mathrm{I}}$ ) and $\beta$-cis (or trans-phenolate, $\mathrm{C}_{\mathrm{II}}$ ) complexes [50]. The ${ }^{51} \mathrm{~V}$ NMR spectra in Fig. 3 show no significant changes in the intensity of the two ${ }^{51} \mathrm{~V}$ NMR signals present in the extracellular medium of the erythrocyte suspensions incubated with the oxidized $\mathrm{V}^{\mathrm{IV}} \mathrm{O}\left(\mathrm{Rpyr}_{2} \mathrm{en}\right)$, assigned to the $\alpha$-cis and $\beta$-cis isomers of $\mathrm{V}^{\mathrm{V}} \mathrm{O}_{2}\left(\mathrm{HRpyr}_{2} \mathrm{en}\right)$, indicating that no significant uptake of this bulky complex is observed using ${ }^{51} \mathrm{~V}$ NMR. The uptake of the complex might occur by passive diffusion of the neutral $\left[\mathrm{V}^{\mathrm{V}} \mathrm{O}_{2}\left(\mathrm{HRpyr}_{2} \mathrm{en}\right)\right]$, which is expected to decrease from $60 \%$ to $40 \%$ mole fraction, when the medium $\mathrm{pH}$ drops from 7.45 to 6.8 after the $8 \mathrm{~h}$ incubation period [50].

The uptake of the $\mathrm{V}^{\mathrm{IV}} \mathrm{O}(\mathrm{dmpp})_{2}$ oxidation products by erythrocytes was also studied using ${ }^{51} \mathrm{~V}$ NMR spectroscopy. In aqueous aerobic unbuffered solution at an initial $\mathrm{pH} 7.4, \mathrm{~V}^{\mathrm{IV}} \mathrm{O}(\mathrm{dmpp})_{2}$ is fully oxidized to two $\mathrm{V}^{\mathrm{V}}$ species with 1:1 and 1:2 stoichiometries, while the solution $\mathrm{pH}$ drops to 4.7 [53]. Fig. 4A shows the ${ }^{51} \mathrm{~V}$ NMR spectra of the extracellular medium of human erythrocyte suspensions, previously incubated with $1 \mathrm{mM}$ oxidized $\mathrm{V}^{\mathrm{IV}} \mathrm{O}(\mathrm{dmpp})_{2}$, as a function of time at two different temperatures: $25^{\circ} \mathrm{C}$ (Fig. $\left.4 \mathrm{~A}(\mathrm{a})\right)$ and $37^{\circ} \mathrm{C}$ (Fig. $4 \mathrm{~A}(\mathrm{~b})$ ). Two ${ }^{51} \mathrm{~V}$ NMR signals are observed at -483 and $-507 \mathrm{ppm}$, corresponding to the 1:2 and 1:1 complexes, respectively [53]. Despite the presence of buffer, the measured $\mathrm{pH}$ dropped to 6.8 along the experiment, as confirmed by the reported ${ }^{51} \mathrm{~V}$ chemical shifts [53]. In these conditions, the 1:2 complex is present exclusively as the mononegative species $\left[\mathrm{V}^{\mathrm{V}} \mathrm{O}_{2}(\mathrm{dmpp})_{2}\right]^{-}$, while the $1: 1 \mathrm{com}$ plex is $11 \%$ in the neutral $\left[\mathrm{V}^{\mathrm{V}} \mathrm{O}_{2}(\mathrm{dmpp})\left(\mathrm{H}_{2} \mathrm{O}\right)_{2}\right]$ form and $89 \%$ present as the negative $\left[\mathrm{V}^{\mathrm{V}} \mathrm{O}_{2}(\mathrm{dmpp})\left(\mathrm{H}_{2} \mathrm{O}\right)(\mathrm{OH})\right]^{-}$ species.

The decrease of the ${ }^{51} \mathrm{~V}$ NMR signal intensity of the two $\mathrm{V}^{\mathrm{V}}$ complexes present in the extracellular medium is considerably faster at $37{ }^{\circ} \mathrm{C}$, and is faster for the negatively charged 1:2 species at both temperatures and at all times, as shown in Fig. $4 \mathrm{~B}(\mathrm{a})$. At $37^{\circ} \mathrm{C}$, the concentration of the $1: 1$ complex decreases to $\sim 23 \%$ of the initial value in $15 \mathrm{~min}$, to $\sim 11 \%$ after $30 \mathrm{~min}$, and then remains constant until $120 \mathrm{~min}$. At $25^{\circ} \mathrm{C}$, it does not change significantly during the first $30 \mathrm{~min}$ and then decreases to approximately $50 \%$ (after $120 \mathrm{~min}$ ). The $1: 2$ species, $\left[\mathrm{V}^{\mathrm{V}} \mathrm{O}_{2} \mathrm{~L}_{2}\right]^{-}$ $(\mathrm{L}=\mathrm{dmpp}$ ) rapidly disappears from the extracellular med- ium at $37{ }^{\circ} \mathrm{C}$, whereas at $25{ }^{\circ} \mathrm{C}$ it decreases to $\sim 32 \%$ after $60 \mathrm{~min}$, with no further change until $120 \mathrm{~min}$. Similar ${ }^{51} \mathrm{~V}$ NMR experiments were carried out in the presence of DIDS, showing that the presence of this anion channel blocker has no significant effect on the time dependent decay of the ${ }^{51} \mathrm{~V}$ NMR signals of both the 1:1 and 1:2 complexes (Fig. 4B(b)).

The absence of any effect of DIDS on the cell uptake of both complexes shows that none of the two negatively charged complexes, $\left[\mathrm{V}^{\mathrm{V}} \mathrm{O}_{2} \mathrm{~L}_{2}\right]^{-}$and $\left[\mathrm{V}^{\mathrm{V}} \mathrm{O}_{2} \mathrm{~L}\left(\mathrm{H}_{2} \mathrm{O}\right)(\mathrm{OH})\right]^{-}$ $(\mathrm{L}=\mathrm{dmpp})$, enters the cells. The large increase in the rate of disappearance of both 1:1 and 1:2 complexes from the extracellular medium upon increasing temperature indicates that the neutral $1: 1$ complex $\left[\mathrm{V}^{\mathrm{V}} \mathrm{O}_{2} \mathrm{~L}\left(\mathrm{H}_{2} \mathrm{O}\right)_{2}\right]$ is the only species taken up by the erythrocytes through passive diffusion, while the negatively charged 1:2 species $\left[\mathrm{V}^{\mathrm{V}} \mathrm{O}_{2} \mathrm{~L}_{2}\right]^{-}$probably decomposes in the extracellular medium to the 1:1 species, which is driven to the neutral form by its cell uptake.

${ }^{1} \mathrm{H}$ NMR spectroscopy was used to confirm this decomposition hypothesis. The ${ }^{1} \mathrm{H}$ NMR signals of free Hdmpp and bound in the $\left[\mathrm{V}^{\mathrm{V}} \mathrm{O}_{2}(\mathrm{dmpp})_{2}\right]^{-}$and $\left[\mathrm{V}^{\mathrm{V}} \mathrm{O}_{2}(\mathrm{dmp}-\right.$ p) $\left(\mathrm{H}_{2} \mathrm{O}\right)_{2}$ ] complexes in solution are observed at different chemical shifts, due to slow exchange NMR conditions [53]. Thus, ${ }^{1} \mathrm{H}$ NMR spectra of the extracellular medium of erythrocyte suspensions incubated with the oxidation products of $\mathrm{V}^{\mathrm{IV}} \mathrm{O}(\mathrm{dmpp})_{2}$ were obtained at different time intervals (data not shown). At $t=0$ min the high frequency spectral region showed two signals at 6.2 and $6.5 \mathrm{ppm}$ that are assigned to the $\mathrm{H} 5$ proton, and two other signals at 7.4 and $7.6 \mathrm{ppm}$ assigned to the $\mathrm{H} 6$ proton of the ligand in the 1:1 and 1:2 species, respectively. After $180 \mathrm{~min}$, these signals significantly decreased in intensity and two doublets at 6.4 and $7.5 \mathrm{ppm}$ appeared, corresponding to the $\mathrm{H} 5$ and $\mathrm{H} 6$ proton signals of the free Hdmpp at the same $\mathrm{pH}$ value [53]. The presence of free ligand in the extracellular medium thus confirms that the 1:2 species decomposes with time, probably into $\left[\mathrm{V}^{\mathrm{V}} \mathrm{O}_{2}(\mathrm{dmpp})\left(\mathrm{H}_{2} \mathrm{O}\right)_{2}\right]$ and free Hdmpp or even vanadate and free ligand $\left({ }^{51} \mathrm{~V}\right.$ NMR spectra of Fig. 4A shows a small signal of free vanadate). The values of the stepwise formation constants reported for the $1: 1$ and $1: 2$ species are $\log K_{1}=10.48$ and $\log K_{2}=5.25$ [53], respectively, supporting the hypothesis that the $1: 2$ species is preferentially decomposed.

Thus, the present experiments provide evidence that only the neutral $1: 1 \mathrm{~V}^{\mathrm{V}}$ species is taken up by the erythrocytes through passive diffusion, and its depletion from the extracellular medium promotes the dissociation of the 1:2 species.

\subsubsection{EPR studies}

The presence of these $\mathrm{V}^{\mathrm{IV}} \mathrm{O}$-signals in erythrocyte lysates confirms the uptake of the vanadium compounds by the cells. Fig. 5 shows EPR spectra of erythrocyte lysates obtained from cell suspensions previously incubated for different time intervals: with vanadate at $25^{\circ} \mathrm{C}$ (Fig. 5A), and oxidation products of $\mathrm{V}^{\mathrm{IV}} \mathrm{O}\left(\mathrm{Rpyr}_{2} \mathrm{en}\right)_{2}$ at $37^{\circ} \mathrm{C}$ 
$\triangle$
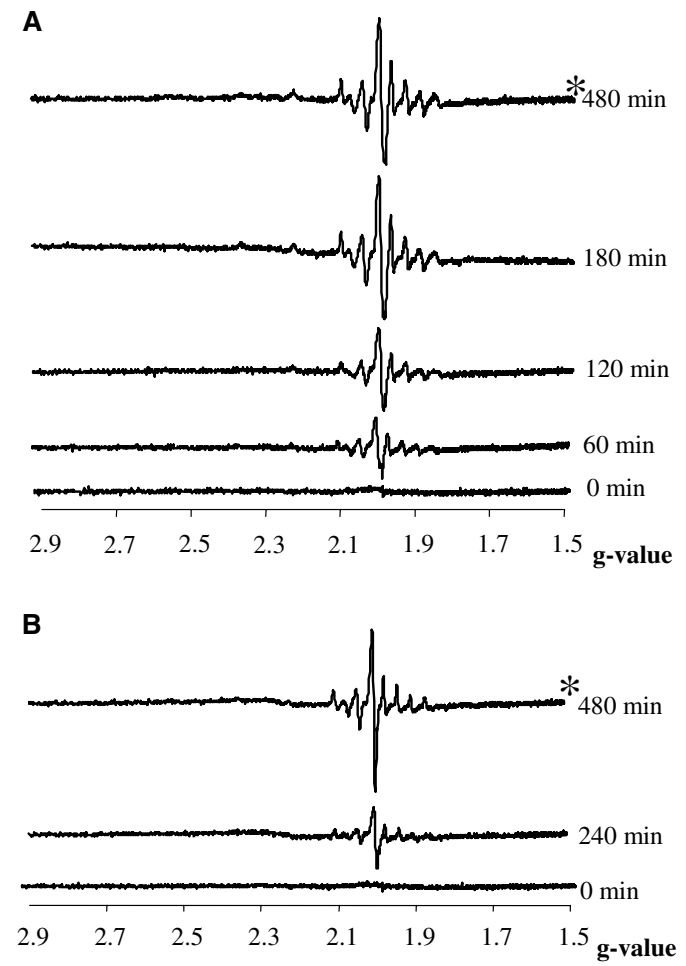
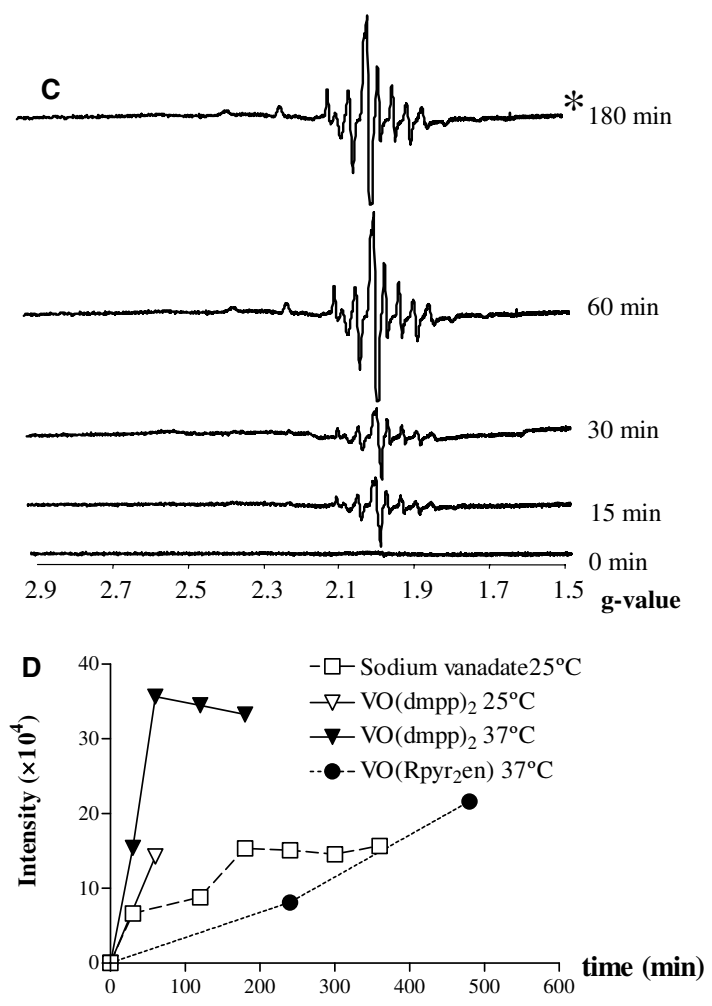

Fig. 5. EPR spectra $(77 \mathrm{~K})$ as a function of time of frozen human erythrocyte lysate samples previously incubated with: (A) $1 \mathrm{mM}$ vanadate at $25^{\circ} \mathrm{C}$; (B) $1 \mathrm{mM}$ oxidized $\mathrm{V}^{\mathrm{IV}} \mathrm{O}\left(\mathrm{Rpyr}_{2} \mathrm{en}\right)$ at $37^{\circ} \mathrm{C}$ and $(\mathrm{C}) 1 \mathrm{mM}$ oxidized $\mathrm{V}^{\mathrm{IV}} \mathrm{O}(\mathrm{dmpp})_{2}$ at $t=37^{\circ} \mathrm{C}$. The spectra marked with * were simulated yielding the parameters included in Table 1. (D) Time dependence of EPR signal intensity measured at the $m_{\mathrm{I}}=-1 / 2_{\perp}$ line upon incubation with vanadate at $25^{\circ} \mathrm{C}$ $(-\square-), \mathrm{V}^{\mathrm{IV}} \mathrm{O}(\mathrm{dmpp})_{2}$ oxidation products at $37^{\circ} \mathrm{C}\left(-\boldsymbol{\nabla}_{-}\right)$and at $25^{\circ} \mathrm{C}(-\nabla-)$, and oxidized $\mathrm{V}^{\mathrm{IV}} \mathrm{O}\left(\mathrm{Rpyr}_{2} \mathrm{en}\right)$ at $37^{\circ} \mathrm{C}(\cdots \bullet \cdots)$.

(Fig. 5B) and $\mathrm{V}^{\mathrm{IV}} \mathrm{O}(\mathrm{dmpp})_{2}$ at $37^{\circ} \mathrm{C}$ (Fig. 5C), while Fig. 5D shows the time dependence of the EPR signal intensity for the incubations carried out at 25 and $37^{\circ} \mathrm{C}$. EPR spectra recorded are relatively weak, especially at low incubation times. This, together with some line broadening, made the high field $m_{\mathrm{I}}=7 / 2_{\|}$line barely discernible in most cases. These features (line broadening and low intensity spectra) are common in in vivo EPR studies [49]. Nevertheless, the $\pm 5 / 2 \|$ and the $\pm 3 / 2 \|$ lines can be seen, even at low incubation times, and the same is true for the $\perp$ part of the spectra, making it possible to accurately simulate the most intense spectrum of each set, thus obtaining the relevant EPR parameters.

EPR spectra of erythrocyte lysates incubated with vanadate show an initial increase in intensity with the incubation time up to $120 \mathrm{~min}$, remaining constant from then on (see Fig. 5A and D). For cells incubated with DIDS during $10 \mathrm{~min}$ prior to the addition of vanadate no EPR signal was detected from the erythrocyte lysates (data not shown). This indicates that vanadium enters the cells as $\mathrm{V}^{\mathrm{V}}$ through the anionic channel which is blocked by DIDS, in agreement with previous studies $[36,66,67]$.

The erythrocyte suspensions incubated with $\mathrm{V}^{\mathrm{IV}} \mathrm{O}\left(\mathrm{Rpyr}_{2} \mathrm{en}\right)$ oxidation products at $37^{\circ} \mathrm{C}$ give lysates with EPR spectra (see Fig. 5B and D) showing low intensity signals that increase slowly with the incubation time, indicating the presence of a minor and slowly increasing concentration of a $\mathrm{V}^{\mathrm{IV}} \mathrm{O}$-species inside the cells, resulting from very slow passive diffusion of the large neutral $\left[\mathrm{V}^{\mathrm{V}} \mathrm{O}_{2}\left(\mathrm{HRpyr}_{2} \mathrm{en}\right)\right]$ complex. These small concentrations of $\mathrm{V}^{\mathrm{IV}} \mathrm{O}$-species are detected by EPR, despite the ${ }^{51} \mathrm{~V}$ NMR data for the incubation medium showing no significant uptake of $\mathrm{V}^{\mathrm{V}} \mathrm{O}_{2} \mathrm{HRpyr}_{2} \mathrm{en}$. This apparent discrepancy results from the much higher sensitivity of EPR vs. NMR.

Overlaying the EPR spectra of erythrocyte lysates incubated with $\mathrm{V}^{\mathrm{IV}} \mathrm{O}\left(\mathrm{Rpyr}_{2} \mathrm{en}\right)$ oxidation products with those of aqueous solutions of the original complex at the relevant $\mathrm{pH}$ values [50] we conclude that the $\mathrm{V}^{\mathrm{IV}} \mathrm{O}$-species detected inside the cells is not likely to be the initial intact complex, although both hyperfine coupling constants $\left(A_{\|}\right.$and $\left.A_{\perp}\right)$ obtained from the spectrum of cell lysates are close to those of $c i s-\mathrm{V}^{\mathrm{IV}} \mathrm{O}\left(\mathrm{HRpyr}_{2} \mathrm{en}\right)$ (see Table 1).

EPR spectra of erythrocyte lysates obtained from cell suspensions incubated with $\mathrm{V}^{\mathrm{IV}} \mathrm{O}(\mathrm{dmpp})_{2}$ oxidation products at $37^{\circ} \mathrm{C}$ (see Fig. 5C and D) show initially a fast increasing signal intensity up to $60 \mathrm{~min}$ incubation time, followed by a constant value. Taking into account the NMR data, we conclude that these EPR spectra result from the passive diffusion of the neutral $\left[\mathrm{V}^{\mathrm{V}} \mathrm{O}_{2}(\mathrm{dmpp})\left(\mathrm{H}_{2} \mathrm{O}\right)_{2}\right]$ complex into the cells, and its subsequent reduction. Concerning the identity of this $\mathrm{V}^{\mathrm{IV}} \mathrm{O}$-species, the calculated EPR parameters (see Table 1) are distinct from those of either $\left[\mathrm{V}^{\mathrm{IV}} \mathrm{O}(\mathrm{dmpp})\left(\mathrm{H}_{2} \mathrm{O}\right)_{2}\right]^{+}$or the cis- and trans$\mathrm{V}^{\mathrm{IV}} \mathrm{O}(\mathrm{dmpp})_{2}$ isomers, indicating that the complex does 
Table 1

Spin Hamiltonian parameters calculated from simulation of X-band EPR spectra (77 K) obtained for: (A) lysed erythrocytes previously incubated at $25^{\circ} \mathrm{C}$ with $\mathrm{Na}_{3} \mathrm{VO}_{4}$, and at $37^{\circ} \mathrm{C}$ with oxidized $\mathrm{V}^{\mathrm{IV}} \mathrm{O}(\mathrm{dmpp})_{2}$ and $\mathrm{V}^{\mathrm{IV}} \mathrm{O}\left(\mathrm{Rpyr}_{2} \mathrm{en}\right)$; (B) dissolution of the $\mathrm{V}^{\mathrm{IV}} \mathrm{O}$ complexes in water in anaerobic conditions; EPR parameters for $\mathrm{V}^{\mathrm{IV}} \mathrm{O}\left(\mathrm{Rpyr}_{2} \mathrm{en}\right)$ and for $\mathrm{V}^{\mathrm{IV}} \mathrm{O}(\mathrm{dmpp})_{2}$ were taken from [50,68], respectively

\begin{tabular}{|c|c|c|c|c|}
\hline & $g_{x, y}\left(g_{\perp}\right)$ & $A_{x, y}\left(A_{\perp}\right) \times 10^{-4} / \mathrm{cm}^{-1}$ & $g_{z}\left(g_{\|}\right)$ & $A_{z}\left(A_{\|}\right) \times 10^{-4} / \mathrm{cm}^{-1}$ \\
\hline \multicolumn{5}{|l|}{$A$} \\
\hline $\mathrm{NaVO}_{3}{ }^{\mathrm{a}}$ & 1.972 & $55 \pm 1$ & 1.948 & $168 \pm 1$ \\
\hline $\mathrm{V}^{\mathrm{IV}} \mathrm{O}\left(\mathrm{Rpyr}_{2} \mathrm{en}\right)^{\mathrm{b}}$ & 1.972 & $51 \pm 1$ & 1.942 & $165 \pm 1$ \\
\hline $\mathrm{V}^{\mathrm{IV}} \mathrm{O}(\mathrm{dmpp})_{2}{ }^{\mathrm{c}}$ & 1.974 & $57 \pm 1$ & 1.945 & $165 \pm 1$ \\
\hline \multicolumn{5}{|l|}{$B$} \\
\hline \multirow[t]{2}{*}{$\mathrm{V}^{\mathrm{IV}} \mathrm{O}\left(\mathrm{Rpyr}_{2} \mathrm{en}\right)\left(\text { in } \mathrm{H}_{2} \mathrm{O}\right)^{\mathrm{d}, \mathrm{e}}$} & 1.981 & 56.0 & 1.953 & $165\left(c i s-\mathrm{H}_{2} \mathrm{O}\right)$ \\
\hline & 1.980 & 50.7 & 1.960 & $157.5\left(\right.$ trans $\left.-\mathrm{H}_{2} \mathrm{O}\right)$ \\
\hline \multirow[t]{3}{*}{$\mathrm{V}^{\mathrm{IV}} \mathrm{O}(\mathrm{dmpp})_{2}\left(\text { in } \mathrm{H}_{2} \mathrm{O}\right)^{\mathrm{h}}$} & $-f ; 1.970^{\mathrm{g}}$ & ${ }_{-}^{\mathrm{f}} ; 58 \pm 1^{\mathrm{g}}$ & $1.939^{\mathrm{f}} ; 1.940^{\mathrm{g}}$ & $170^{\mathrm{f}} ; 170 \pm 1^{\mathrm{g}}$ \\
\hline & $-{ }^{f} ; 1.972^{g}$ & ${ }^{\text {ff }} ; 57 \pm 2^{\mathrm{g}}$ & $1.940^{\mathrm{f}} ; 1.944^{\mathrm{g}}$ & $166^{f} ; 163 \pm 2^{g}$ \\
\hline & ${ }_{-}^{\mathrm{f}} ; 1.973^{\mathrm{g}}$ & $-f^{f} ; 53 \pm 2^{\mathrm{g}}$ & $1.950^{\mathrm{f}} ; 1.959^{\mathrm{g}}$ & $157^{\mathrm{f}} ; 156 \pm 2^{\mathrm{g}}$ \\
\hline
\end{tabular}

${ }^{\text {a }}$ Parameters obtained from the spectrum recorded after a 480 min incubation period.

${ }^{\text {b }}$ Parameters obtained from the spectrum recorded after a $480 \mathrm{~min}$ incubation period.

${ }^{\mathrm{c}}$ Parameters obtained from the spectrum recorded after a $180 \mathrm{~min}$ incubation period.

d $\mathrm{pH} 7$.

e The two species detected are assigned to isomers with equatorially ( $\mathrm{cis}$ ) or axially (trans) coordinated water [50].

${ }^{\mathrm{f}}$ Taken from [68].

g $\sim 1 \mathrm{mM}$ in water:ethyleneglycol solution (9:1).

${ }^{\mathrm{h}}$ The three species present were assigned to the 1:1 complex, and to the two 1:2 isomers (with the water molecule coordinated either equatorially or axially).

not maintain its identity inside the cells. The uptake of the $\mathrm{V}^{\mathrm{IV}} \mathrm{O}(\mathrm{dmpp})_{2}$ oxidation products was also found to be temperature dependent, the initial EPR signal intensity at 60 min being, ca. 2.5 lower at $25^{\circ} \mathrm{C}$ than at $37^{\circ} \mathrm{C}$ (Fig. 5D).

As indicated by the intensity of the EPR signals (Fig. 5D), of the two vanadium compounds tested at $37^{\circ} \mathrm{C}$, the oxidized $\mathrm{V}^{\mathrm{IV}} \mathrm{O}(\mathrm{dmpp})_{2}$ is the one more easily taken up by the erythrocytes, and to a higher extent. After an incubation time of $60 \mathrm{~min}$, the corresponding EPR signal is $\sim 1.5$ times more intense than that of the oxidized $\mathrm{V}^{\mathrm{IV}} \mathrm{O}\left(\mathrm{Rpyr}_{2} \mathrm{en}\right)$ after a 480 min incubation period. The entry of $\mathrm{V}^{\mathrm{IV}} \mathrm{O}(\mathrm{dmpp})_{2}$ oxidation products is also faster than that of the vanadate salt, the corresponding EPR spectrum being more intense by a factor of $\sim 2.2$ at $25^{\circ} \mathrm{C}$ (for a $60 \mathrm{~min}$ incubation period) (Fig. 5D).

For all vanadium compounds tested the intensity of the EPR signal increases with the incubation time but there are no changes in its features with time. This indicates an increase in the concentration of the same $\mathrm{V}^{\mathrm{IV}} \mathrm{O}$ species in the cells for each set of compounds studied. The EPR spectra of cell lysates incubated with aqueous solutions of vanadate, $\mathrm{V}^{\mathrm{IV}} \mathrm{O}(\mathrm{dmpp})_{2}$ and $\mathrm{V}^{\mathrm{IV}} \mathrm{O}\left(\mathrm{Rpyr}_{2} \mathrm{en}\right)$ are similar but differ from those of the original complex. This suggests that all $\mathrm{V}^{\mathrm{IV}} \mathrm{O}$-complexes are decomposed (partially or totally), and that the metal binds to a similar set of donor atoms of intracellular ligands. EPR of $\mathrm{V}^{\mathrm{IV}} \mathrm{O}$-compounds is very sensitive to the type of "equatorial" donors, charge of complex and type of bonds formed. The small differences detected might indicate a similar set of donor atoms placed into a slightly different environment (see Fig. 6). The EPR signals obtained from erythrocyte lysates incubated with vanadate are also broader than those incubated with both $\mathrm{V}^{\mathrm{IV}} \mathrm{O}$ complexes. This inhomogeneous line broaden-

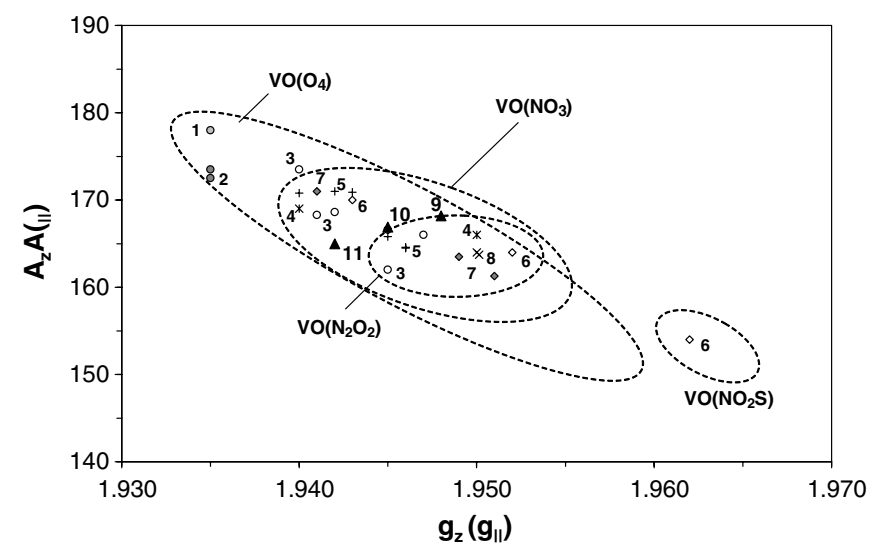

Fig. 6. Graphical representation of the correlation between $A_{\|}$and $g_{\|}$for several $\mathrm{V}^{\mathrm{IV}} \mathrm{O}^{2+}$ complexes in frozen aqueous solution $(77 \mathrm{~K})$ most from in vivo/in vitro studies. Dotted lines define approximate domains for the range of values corresponding to the equatorial ligand fields specified $[46,55]$. Represented data are as follows: 1 . (light grey circle) $\mathrm{V}^{\mathrm{IV}} \mathrm{O}-\mathrm{ATP}$ complex [45]; 2. (dark grey circles) rat bone samples incubated with $\mathrm{V}^{\mathrm{IV}} \mathrm{OSO}_{4}$ and $\mathrm{VO}(\text { pic })_{2}$ [45]; 3. (open circles) BSA aqueous solution [48]; 4. (asterisks) rat kidney incubated with $\mathrm{V}^{\mathrm{IV}} \mathrm{OSO}_{4}$ and $\mathrm{V}^{\mathrm{IV}} \mathrm{O}(\text { pic })_{2}[48]$; 5. (+) rat blood incubated with $\mathrm{V}^{\mathrm{IV}} \mathrm{OSO}_{4}, \mathrm{~V}^{\mathrm{IV}} \mathrm{O}(\mathrm{Me}-\mathrm{pic})_{2}$ and $\mathrm{V}^{\mathrm{IV}} \mathrm{O}(\mathrm{pic})_{2}$ ( $\mathrm{Me}=$ methyl) [48] 6. (white lozenges): $\mathrm{V}^{\mathrm{IV}} \mathrm{O}-\mathrm{GSH}$ complexes at $\mathrm{pH}$ $\sim 6.5-7$ [44]; 7. (grey lozenges): $\mathrm{V}^{\mathrm{IV}} \mathrm{O}-\mathrm{GSSG}$ complexes at $\mathrm{pH} \sim 6.5-7$ [43]; 8. ( $\times$ ) rat adipocytes incubated with $\mathrm{V}^{\mathrm{IV}} \mathrm{OSO}_{4}$ [45]; 9. (dark triangles) human erythrocyte cells incubated with vanadate (this work); 10. (dark triangles): oxidized $\mathrm{V}^{\mathrm{IV}} \mathrm{O}(\mathrm{dmpp})_{2}$ (this work); 11. (dark triangles): oxidized $\mathrm{V}^{\mathrm{IV}} \mathrm{O}\left(\mathrm{Rpyr}_{2} \mathrm{en}\right)$ (this work).

ing is possibly due to the presence of more than one $\mathrm{V}^{\mathrm{IV}} \mathrm{O}$ species with EPR parameters too close to be distinguished [47].

The additivity rule for $A_{\|}$and $g_{\|}$can be used to predict the $\mathrm{V}^{\mathrm{IV}} \mathrm{O}$ equatorial coordination environment of the $\mathrm{V}^{\mathrm{IV}} \mathrm{O}$-species detected. In the present case, this may be 
more clearly assessed through a representation of the EPR parameters in $g_{\|}-A_{\|}$diagrams [45,56,59]. Fig. 6 compares a display of data from our study with erythrocytes (dark triangles, points 9, 10 and 11) with related in vivo and in vitro literature data. Our parameters fit well to both a $\mathrm{VO}\left(\mathrm{N}_{2} \mathrm{O}_{2}\right)$ or a $\mathrm{VO}\left(\mathrm{NO}_{3}\right)$ donor atom set, where $\mathrm{N}$ may be e.g. an amine, imine or imidazole (or other), and $\mathrm{O}$ could correspond to, e.g. phosphate, carboxylate, or $\mathrm{O}_{\text {phenolate }}$ (or other). The estimated $A_{\|}$and $g_{\|}$values are too low for a $\mathrm{VO}\left(\mathrm{O}_{4}\right)$ binding mode, which are therefore less likely. Nevertheless, the intensity of the EPR signal is always low, and given the range of different values that $\mathrm{O}$ donors may assume, the $\mathrm{VO}\left(\mathrm{O}_{4}\right)$ coordination environment cannot be completely excluded. However, for a $\mathrm{VO}^{\mathrm{IV}}\left(\mathrm{O}_{4}\right)$ donor set, $A_{\|}$values lower than ca. $160 \times 10^{-4} \mathrm{~cm}^{-1}$ can only be obtained including as in-plane $\mathrm{O}^{-}$donors: $\mathrm{O}_{\text {phenolate}}$, $\mathrm{OH}^{-}$or alcoholate- $\mathrm{O}^{-}$. $\mathrm{VO}^{\mathrm{IV}}(\text { catecholate })_{2}$ corresponds to $g_{\|}, A_{\|}$points far from those of 9,10 or 11 , but donor sets including one/two $\mathrm{O}_{\text {phenolate }}^{-}$, or one $\mathrm{OH}^{-}$donors are possible, while alcoholate- $\mathrm{O}^{-}$is not. Possibly one/two of the oxygen donor atoms are not as hard as in $\mathrm{H}_{2} \mathrm{O}$ or carboxylate coordination, being closer to $\mathrm{O}_{\text {phenolate-type atoms, }}$ but their exact nature cannot be identified. Several plausible ligands are present: histidine, tyrosine, GSH, GSSG $[43,44]$, ATP $[69,70]$ and hemoglobin. With such a large number of available binding-sites, it is not possible to identify which specific interactions (with an enzyme or protein or smaller ligand) are operating. The binding of $\mathrm{V}^{\mathrm{IV}} \mathrm{O}^{2+}$ exclusively to ATP, GSH or GSSG (points 1, 6 and 7, respectively, in Fig. 6) can however be excluded in the erythrocyte case.

We should briefly mention other possible vanadium species that can be present in the cells besides the EPR-active $\mathrm{V}^{\mathrm{IV}} \mathrm{O}$-species. Erythrocyte lysates could also contain dimeric or oligomeric $\mathrm{V}^{\mathrm{IV}}$ species $[2,55,71]$ which would be EPR-silent. It is very unlikely that these diamagnetic $\mathrm{V}^{\mathrm{IV}}$ species would be important in a rich ligand environment such as a cell, which contains a variety of proteins, peptides and other biological compounds that are effective vanadium binders. Some vanadium could also be present as $\mathrm{V}^{\mathrm{III}}$ or $\mathrm{V}^{\mathrm{V}} \cdot \mathrm{V}^{\mathrm{V}}$-species which are believed to be easily reduced in the thiol-rich erythrocyte intracellular environment, as shown by EPR studies [7].

\subsection{Oxidative stress induced by oxovanadium compounds}

Oxidative stress induced by vanadate and the oxidation products of the oxovanadium(IV) compounds in erythrocytes was characterized by measuring their effect on the pentose phosphate pathway (PP) flux of erythrocyte suspensions [62]. In these cells, the oxidative branch of the PP generates NADPH, which is almost entirely used in the regeneration of reduced glutathione by NADP-glutathione reductase. Oxidative stress will accelerate glutathione cycling (GSH $\leftrightarrow$ GSSG), which results in increased NADPH consumption and stimulation of PP flux [72]. PP fluxes were estimated from the ratio of excess ${ }^{13} \mathrm{C}$ - enrichment in lactate carbon 3 relative to carbon 2, according to established metabolic models [62].

As shown in Fig. 7A and inset (a), the ${ }^{1} \mathrm{H}$ NMR spectrum of the methyl group of lactate has well-resolved signals from ${ }^{13} \mathrm{C}$-isotopomers formed as a result of $\left[2-{ }^{13} \mathrm{C}\right]$ glucose metabolism through the glycolytic and PP pathways, which correspond to ${ }^{13} \mathrm{C}$ enrichment of lactate in carbon $2(\mathrm{Q} 2$ signal) and in carbon $3(\mathrm{Q} 3$ signal), respectively [62]. In quiescent erythrocytes, the control group, ${ }^{13} \mathrm{C}$ enrichment of lactate carbon 3 relative to carbon 2 (C3/C2) was low $(6.8 \pm 2.5 \%)$, consistent with baseline PP activity



B

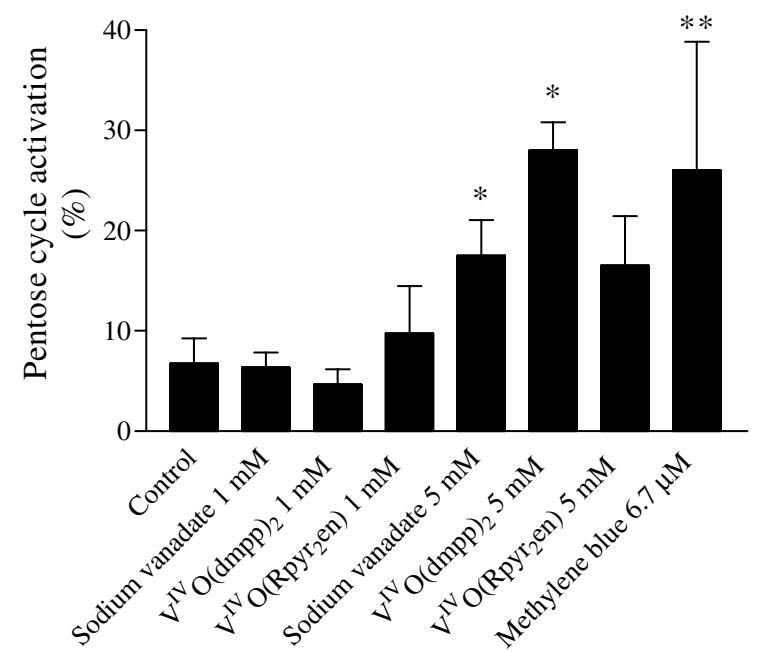

Fig. 7. (A) ${ }^{1} \mathrm{H}$ NMR spectrum showing the lactate methyl signal of the extracellular medium obtained from an erythrocyte suspension treated with methylene blue at $37{ }^{\circ} \mathrm{C}$. The signal feature contributions from ${ }^{12} \mathrm{C}$ lactate (D), $\left[2-{ }^{13} \mathrm{C}\right]$ lactate, (Q2) and $\left[3-{ }^{13} \mathrm{C}\right]$ lactate, (Q3). Inset (a) shows an expansion of the D and Q2 components of the spectrum; (B) graphical representation of the pentose cycle activation effect due to the presence of 1 and $5 \mathrm{mM}$ vanadate, $\mathrm{V}^{\mathrm{IV}} \mathrm{O}\left(\mathrm{Rpyr}_{2} \mathrm{en}\right)$ and $\mathrm{V}^{\mathrm{IV}} \mathrm{O}(\mathrm{dmpp})_{2}$ oxidation products, compared with a control group and a group stimulated with methylene blue. Values are given as mean $\pm \operatorname{SEM}(n=5$ for the control group and for the group treated with methylene blue; $n=3$ for the groups treated with vanadate and the oxovanadium compounds; ${ }^{* *} p<0.01$ relative to the control and ${ }^{*} p<0.05$ relative to the control). 
of erythrocytes. In the presence of methylene blue, a classical activator of erythrocyte glutathione oxidation, lactate $\mathrm{C} 3 / \mathrm{C} 2$ ratio was substantially higher $(26.0 \pm 12.9 \%)$, reflecting a significant $(p<0.01)$ activation of PP flux and generation of NADPH for the glutathione redox cycle [62].

${ }^{1}$ H NMR spectra with similar features were obtained when vanadate and the oxovanadium compounds were tested in 1 and $5 \mathrm{mM}$ concentration. Fig. $7 \mathrm{~B}$ shows the results obtained from ${ }^{1} \mathrm{H}$ NMR data. The value of pentose cycle activation obtained for the group stimulated with $1 \mathrm{mM}$ vanadate is $6.3 \pm 1.5 \%$, which does not differ significantly $(p>0.05)$ from the control, but is significantly different $(p<0.05)$ from the group treated with methylene blue. The same happens when stimulation with $1 \mathrm{mM} \mathrm{V} \mathrm{V}^{\mathrm{IV}} \mathrm{O}\left(\mathrm{Rpyr}_{2} \mathrm{en}\right)$ or $1 \mathrm{mM} \mathrm{V} \mathrm{V}^{\mathrm{IV}} \mathrm{O}(\mathrm{dmpp})_{2}$ oxidation products occurs, where the pentose cycle activation is $9.8 \pm 4.7 \%$ and $4.7 \pm 1.5 \%(p<0.05$ relative to the group treated with methylene blue), respectively. These results indicate that vanadate and the oxovanadium compounds tested do not significantly activate the pentose cycle in the $1 \mathrm{mM}$ concentration used, showing that the oxidative stress induced by these vanadium compounds in the present conditions is negligible, as far as erythrocytes are concerned.

At $5 \mathrm{mM}$ all the vanadium compounds tested show increased induced oxidative stress. The value of pentose cycle activation obtained for the group stimulated with $5 \mathrm{mM}$ vanadate is $17.5 \pm 3.5 \%$, which differs significantly from the control $(p<0.05)$. The same happens by stimulation with $5 \mathrm{mM}$ oxidized $\mathrm{V}^{\mathrm{IV}} \mathrm{O}(\mathrm{dmpp})_{2}$, where the pentose cycle activation is $28.0 \pm 2.8 \% \quad(p<0.05)$. The oxidized $\mathrm{V}^{\mathrm{IV}} \mathrm{O}\left(\mathrm{Rpyr}_{2}\right.$ en $)$ does not significantly stimulate the pentose cycle $(16.5 \pm 5.0 \%)(p>0.05)$ relative to the control group, which is in agreement with the very slow entry observed for this vanadium compound in erythrocytes. The oxidative stress induced by the vanadium compounds is closely related with the amount of vanadium delivered by them inside the cells. Thus, it is not surprising that PP flux stimulation by the vanadium compounds at $5 \mathrm{mM}$ follows the order oxidized $\mathrm{V}^{\mathrm{IV}} \mathrm{O}\left(\mathrm{Rpyr}_{2} \mathrm{en}\right)<$ vanadate $<$ oxidized $\mathrm{V}^{\mathrm{IV}} \mathrm{O}(\mathrm{dmpp})_{2}$, since this is the order of increasing vanadium content in the cells.

Previous toxicity tests carried out with a large number of vanadium compounds on transformed fibroblasts from mice (cell line SV 3T3) showed that toxic effects increase with increasing exposure time of the cells to the vanadium compounds, and that most of the vanadium compounds studied, including $\mathrm{V}^{\mathrm{IV}} \mathrm{O}(\mathrm{dmpp})_{2}$ and vanadate, are toxic at $1 \mathrm{mM}$ concentration, but not $\mathrm{V}^{\mathrm{IV}} \mathrm{O}\left(\mathrm{Rpyr}_{2} \mathrm{en}\right)$, which is in agreement with our results [18]. Although vanadium toxicity depends on many factors besides oxidative stress, and its assessment depends on the method used, we emphasize that these toxicity results reported in the literature correlate well with the oxidative stress data obtained in this work, as assessed by the activation of the PP flux in erythrocytes exposed to $5 \mathrm{mM}$ vanadium compounds.

\subsection{Glucose intake in the presence of oxovanadium compounds}

The glucose present in the extracellular medium of erythrocyte suspensions after incubation with $1 \mathrm{mM}$ vanadate or oxovanadium compounds at $37^{\circ} \mathrm{C}$ during $8 \mathrm{~h}$ was determined using a biochemical assay. The hexokinase method provides a high degree of specificity for estimating glucose [73], whereby glucose is measured by quantifying the reduced NADPH formed from the net reactions catalyzed by hexokinase and glucose-6-phosphate dehydrogenase [63]. Fig. 8 shows that at $37^{\circ} \mathrm{C}$ and $1 \mathrm{mM}$ concentration only oxidized $\mathrm{V}^{\mathrm{IV}} \mathrm{O}(\mathrm{dmpp})_{2}$ significantly increased the glucose intake rate $(0.75 \pm 0.13 \mathrm{mM} / \mathrm{h}, p<0.05)$ by erythrocytes relative to the control $(0.37 \pm 0.17 \mathrm{mM} / \mathrm{h})$. At room temperature and in the whole blood without addition of a glycolysis inhibitor, glucose is metabolized at a rate higher than that observed for the control group (approximately $0.4 \mathrm{mM} / \mathrm{h}$ [74]), especially if it is taken into account that this rate value was obtained at $37^{\circ} \mathrm{C}$. However, in this study erythrocyte suspensions were used instead of the whole blood, and the experiments were carried out during several hours without perfusion. This might have affected cellular metabolism and consequently the glucose intake rate. Glucose intake rates for the groups stimulated with vanadate $(0.46 \pm 0.05 \mathrm{mM} / \mathrm{h})$ and oxidized $\mathrm{V}^{\mathrm{IV}} \mathrm{O}\left(\mathrm{Rpyr}_{2} \mathrm{en}\right)(0.51 \pm 0.11 \mathrm{mM} / \mathrm{h})$ do not significantly $(p>0.05)$ increase relative to the control. The group stimulated with methylene blue, used as a negative control in the oxidative stress experiments, also showed a significant $(p<0.05)$ increase in the glucose intake rate $(0.90 \pm$ $0.12 \mathrm{mM} / \mathrm{h}$ ) relative to the control, which is closely related to the observed increase in PP flux (see Fig. 7B). The fact that only stimulation with oxidized $\mathrm{V}^{\mathrm{IV}} \mathrm{O}(\mathrm{dmpp})_{2}$ had an effect on glucose intake rate may be strongly related with the larger amount of vanadium taken up by the cells in this

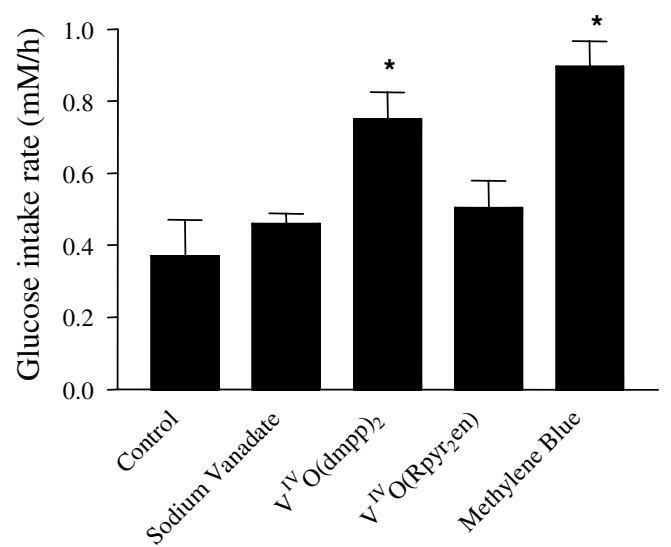

Fig. 8. Graphical representation of glucose consumption rate obtained from erythrocyte suspensions incubated with $1 \mathrm{mM}$ vanadate, $1 \mathrm{mM}$ of oxidation products of the oxovanadium compounds, $\mathrm{V}^{\mathrm{IV}} \mathrm{O}\left(\mathrm{Rpyr}_{2} \mathrm{en}\right)$ and $\mathrm{V}^{\mathrm{IV}} \mathrm{O}(\mathrm{dmpp})_{2}$, and $6.7 \mu \mathrm{M}$ methylene blue during $8 \mathrm{~h}$ at $37^{\circ} \mathrm{C}$, as well as those obtained from a control cell suspension. Values are given as mean $\pm \operatorname{SEM}\left(n=3 ;{ }^{*} p<0.05\right.$ relative to the control). 
case, as a result of the facilitated influx of this compound by passive diffusion.

It is known from in vivo studies that the serum levels of glucose and free fatty acids (FFA) correlate well in normal and STZ rats, and that the FFA serum level is a good index of the degree of Diabetes Mellitus [75,11]. Previous studies with $\mathrm{V}^{\mathrm{IV}} \mathrm{O}(\mathrm{dmpp})_{2}$ showed a dose-dependent inhibitory effect on the FFA release from epinephrine-stimulated rat adipocytes in the presence of glucose. $\mathrm{V}^{\mathrm{IV}} \mathrm{O}(\mathrm{dmpp})_{2}$ is effective at concentrations that are 5.7 times lower than that observed for vanadyl sulfate. Moreover, $\mathrm{IC}_{50}$ values for $\mathrm{V}^{\mathrm{IV}} \mathrm{O}(\mathrm{dmpp})_{2}$ are approximately half of that observed for vanadyl sulfate [54]. Another study reported that in $\mathrm{Hu}-$ man and SV 3T3 fibroblasts, $1 \mathrm{mM} \mathrm{V} \mathrm{V}^{\mathrm{IV}} \mathrm{O}(\mathrm{dmpp})_{2}$ affects glucose intake in a similar level of that observed in the same conditions for the same concentration of insulin, whereas on SV $3 \mathrm{~T} 3$ fibroblasts $\mathrm{V}^{\mathrm{IV}} \mathrm{O}\left(\mathrm{Rpyr}_{2} \mathrm{en}\right)$ is more effective than insulin in concentrations of the compound lower than $1 \mathrm{mM}$ [18]. The insulin mimetism observed in the mentioned studies, for the vanadium compound $\mathrm{V}^{\mathrm{IV}} \mathrm{O}(\mathrm{dmpp})_{2}$, with coordination mode $\mathrm{VO}\left(\mathrm{O}_{4}\right)$, is in agreement with another study where similar properties were observed for the vanadium compounds with the same coordination mode $[26,27]$.

\section{Concluding remarks}

The interaction of the oxidation products of two oxovanadium(IV) compounds, $\mathrm{V}^{\mathrm{IV}} \mathrm{O}\left(\mathrm{Rpyr}_{2}\right.$ en $)$ and $\mathrm{V}^{\mathrm{IV}} \mathrm{O}(\mathrm{dmpp})_{2}$, with human erythrocytes was studied to mimic some of the biological events that might occur in blood, following the oral administration of the complexes. The decrease with time of the intensity of ${ }^{51} \mathrm{~V}$ NMR signals of $\mathrm{V}^{\mathrm{V}}$ species present in the extracellular medium of erythrocyte suspensions indicates their uptake by the cells. On the other hand, the increasing intensity of the $\mathrm{V}^{\mathrm{IV}} \mathrm{O}$ EPR signal observed with time in the erythrocyte lysates indicates the presence of $\mathrm{V}^{\mathrm{IV}}$ paramagnetic species inside the cells. This means that the cells are taking up the vanadium which is then reduced inside the cells to new $\mathrm{V}^{\mathrm{IV}} \mathrm{O}$-species, most likely with a $\mathrm{VO}\left(\mathrm{NO}_{3}\right)$ or $\mathrm{VO}\left(\mathrm{N}_{2} \mathrm{O}_{2}\right)$ binding mode. However, the small differences observed in the EPR signals indicate that the species detected is not the same in each set of spectra corresponding to each vanadium compound. The data indicate that the ligand is partially or totally replaced, but total replacement by ATP, GSH or GSSG is excluded.

The uptake results indicate that the neutral $\mathrm{V}^{\mathrm{V}} \mathrm{O}_{2}\left(\mathrm{HRpyr}_{2}\right.$ en $)$ species slowly enters the cells by passive diffusion. This compound does not promote oxidative stress in erythrocytes at $1 \mathrm{mM}$ concentration and its effect on glucose intake by erythrocytes is negligible. In aqueous aerobic solution $\mathrm{V}^{\mathrm{IV}} \mathrm{O}(\mathrm{dmpp})_{2}$ is fully oxidized after $12 \mathrm{~h}$ to two $\mathrm{V}^{\mathrm{V}}$ complexes with different stoichiometries. The neutral 1:1 species $\left[\mathrm{V}^{\mathrm{V}} \mathrm{O}_{2}(\mathrm{dmpp})\left(\mathrm{H}_{2} \mathrm{O}\right)_{2}\right]$ rapidly enters the erythrocytes by passive diffusion, with an influx rate faster than for $\mathrm{V}^{\mathrm{V}} \mathrm{O}_{2}\left(\mathrm{HRpyr}_{2} \mathrm{en}\right)$. Once inside the cells, it is reduced to $\mathrm{V}^{\mathrm{IV}} \mathrm{O}$-species. An increase in glucose intake rela- tive to the control was observed when the cells were incubated with $1 \mathrm{mM}$ of this compound. This occurs without a concomitant increase of the PP flux. Thus, oxidized $\mathrm{V}^{\mathrm{IV}} \mathrm{O}(\mathrm{dmpp})_{2}$ activates glycolysis by a factor of about two relative to the control, without induced oxidative stress.

The methodology described in this work, when extended to insulin target cells, such as adipocytes or hepatocytes, can be an informative tool to study some relevant properties of the potential insulin mimetic vanadium compounds synthesized worldwide, and thus play an important role in the selection of compounds for further in vitro and in vivo studies.

\section{Acknowledgments}

Financial support from Fundação para a Ciência e Tecnologia, Portugal (FCT projects POCTI/35368/1999 and POCTI/56949/2004) and FEDER is acknowledged. T.D. was supported by a BTI-03-03 Grant included in the first FCT project. I.T. thanks FCT for the Grant SFRH/BPD/11536/2002. This work was carried out within the working group "Vanadium Compounds as Insulin Mimetic Agents" of the COST D21 Action of the European Union.

\section{References}

[1] K.H. Thompson, J.H. McNeill, C. Orvig, Chem. Rev. 99 (1999) 25612571.

[2] D.C. Crans, J.J. Smee, E. Gaidamauskas, L. Yang, Chem. Rev. 104 (2004) 849-902.

[3] J.O. Nriagu (Ed.), Vanadium in the Environment, Wiley, New York, 1998.

[4] K.H. Thompson, C. Orvig, Coord. Chem. Rev. 219-221 (2001) 10331053.

[5] M. Bollen, M. Miralpeix, F. Ventura, B. Toth, R. Bartrons, W. Stalmans, Biochem. J. 267 (1990) 269-271.

[6] V.C. Sálice, A.M. Cortizo, C.L. Gómez Dumm, S.B. Etcheverry, Mol. Cell. Biochem. 198 (1999) 119-128.

[7] S.B. Etcheverry, D.C. Crans, A.D. Keramidas, A.M. Cortizo, Arch. Biochem. Biophys. 338 (1997) 7-14.

[8] R.J. Germinario, S.P. Colby-Germinario, B.I. Posner, K. Nahm, J. Biomed. Biotechnol. 2 (2002) 22-30.

[9] W.C. Duckworth, S.S. Solomon, J. Liepnicks, F.G. Hamel, S. Hand, D.E. Peavy, Endocrinology 122 (1988) 2285-2289.

[10] B. Lu, D. Ennis, R. Lai, E. Bogdanovic, R. Nikolov, L. Salamon, C. Fantus, H. Le-Tien, I.G. Fantus, J. Biol. Chem. 276 (2001) 35589 35598.

[11] H. Sakurai, K. Tsuchiya, M. Nukatsuka, M. Sofue, J. Kawada, J. Endocrinol. 126 (1990) 451-459.

[12] V.G. Yuen, R.A. Pederson, S. Dai, C. Orvig, J.H. Mcneill, Can. J. Physiol. Pharmacol. 74 (1996) 1001-1009.

[13] S.M. Brichard, J.C. Henquin, Trends Pharmacol. Sci. 16 (1995) $265-$ 270.

[14] J.L. Domingo, Mol. Cell. Biochem. 203 (2000) 185-187.

[15] H. Sakurai, H. Yasui, Y. Adachi, Expert. Opin. Investig. Drugs 12 (2003) 1189-1203.

[16] J.H. McNeill, V.G. Yuen, H. Hoveyda, C. Orvig, J. Med. Chem. 35 (1992) 1489-1491.

[17] H. Sakurai, Y. Fujisawa, S. Fujimoto, H. Yasui, T. Takino, J. Trace Elem. Exp. Med. 12 (1999) 393-401. 
[18] D. Rehder, J. Costa Pessoa, C.F. Geraldes, M.M. Castro, T.A. Kabanos, T. Kiss, B. Meier, G. Micera, L. Pettersson, M. Rangel, A. Salifoglou, I. Turel, D. Wang, J. Biol. Inorg. Chem. 7 (2002) 384-396.

[19] K. Cusi, S. Cukier, R. DeFronzo, M. Torres, F. Puchulu, J. Redondo, J. Clin. Endocrinol. Metab. 86 (2001) 1411-1417.

[20] P.J. Stankiewicz, M.J. Gresser, M.J. Tracey, L.F. Hass, Biochemistry 26 (1987) 1264-1269.

[21] G. Swarup, S. Cohen, D.L. Garbers, Biochem. Biophys. Res Commun. 107 (1982) 1104-1109.

[22] B.I. Posner, R. Faure, J.W. Burgess, A.P. Bevan, D. Lachance, G. Zhang-Sun, I.G. Fantus, J.B. Ng, D.A. Hall, B. Lum, A. Shaver, J. Biol. Chem. 269 (1994) 4596-4604.

[23] A.P. Bevan, P.G. Drake, J.F. Yale, A. Shaver, B.I. Posner, Mol. Cell. Biochem. 153 (1995) 49-58.

[24] K.G. Peters, M.G. Davis, B.W. Howard, M. Pokross, V. Rastogi, C. Diven, K.D. Greis, E. Eby-Wilkens, M. Maier, A. Evdokimov, S. Soper, F. Genbauffe, J. Inorg. Biochem. 96 (2003) 321-330.

[25] J. Fugono, H. Yasui, H. Sakurai, J. Pharm. Pharmacol. 53 (2001) $1247-1255$.

[26] A. Katoh, K. Taguchi, H. Okada, M. Harata, Y. Fujisawa, T. Takino, H. Sakurai, Chem. Lett. 866 (2000).

[27] A. Katoh, K. Taguchi, R. Saito, Y. Fujisawa, T. Takino, H. Sakuari, Heterocycles 60 (2003) 1147-1159.

[28] V.G. Yuen, C. Orvig, J.H. McNeill, Can. J. Physiol. Pharmacol. 71 (1993) 263-269.

[29] G.R. Hanson, Y. Sun, C. Orvig, Inorg. Chem. 35 (1996) 6507-6512.

[30] B.D. Liboiron, K.H. Thompson, G.R. Hanson, E. Lam, N. Aebischer, C. Orvig, J. Am. Chem. Soc. 127 (2005) 5104-5115.

[31] D.C. Crans, J. Inorg. Biochem. 80 (2000) 123-131.

[32] J. Fugono, H. Yasui, H. Sakuarai, J. Pharm. Pharmacol. 54 (2002) 611-615.

[33] H. Sakurai, The Chemical Record 2 (2002) 237-248.

[34] H. Sakurai, J. Fugono, H. Yasui, Mini-Reviews in Medical Chemistry 4 (2004) 41-48.

[35] B.R. Nechay, Annu. Rev. Pharmacol. Toxicol. 24 (1984) 501-524.

[36] L.C. Cantley Jr., M.D. Resh, G. Guidotti, Nature 272 (1978) 552-554.

[37] M. Garner, J. Reglinski, W.E. Smith, J. McMurray, I. Abdullah, R. Wilson, J. Biol. Inorg. Chem. 2 (1997) 235-241.

[38] J.E. Benabe, J. Biol. Chem. 262 (1987) 9555-9560.

[39] L.C. Cantley Jr., P. Aisen, J. Biol. Chem. 254 (1979) 1781-1784.

[40] I.G. Macara, K. Kustin, L.C. Jr Cantley, Biochim. Biophys. Acta 629 (1980) 96-106.

[41] A. Dessi, G. Micera, D. Sanna, J. Inorg. Biochem. 52 (1993) 275-286.

[42] E.G. Ferrer, P.A. Williams, E.J. Baran, J. Inorg. Biochem. 50 (1993) 253-262.

[43] J. Costa Pessoa, I. Tomaz, T. Kiss, P. Buglyó, J. Inorg. Biochem. 84 (2001) 259-270.

[44] J. Costa Pessoa, I. Tomaz, T. Kiss, E. Kiss, P. Buglyó, J. Biol. Inorg. Chem. 7 (2002) 225-240.

[45] K. Fukui, H. Ohya-Nishigushi, M. Nakai, Y. Fujisawa, H. Sakurai, H. Kamada, J. Inorg. Biochem. 77 (1999) 215-224.

[46] H. Sakurai, S. Shimomura, K. Fukuzawa, K. Ishizu, Biochim. Biophys. Res. Commun. 96 (1980) 293-298.

[47] K. Fukui, H. Ohya-Nishiguchi, M. Nakai, H. Sakurai, H. Kamada, FEBS Lett. 368 (1995) 31-35.

[48] H. Yasui, K. Takechi, H. Sakurai, J. Inorg. Biochem. 78 (2000) $185-$ 196.
[49] T. Takino, H. Yasui, A. Yoshitake, Y. Hamajima, R. Matsushita, J. Takada, H. Sakurai, J. Biol. Inorg. Chem. 6 (2001) 133-142.

[50] I. Correia, J. Costa Pessoa, M.T. Duarte, R.T. Henriques, M.F. Piedade, L.F. Veiros, T. Jakusch, A. Dörnyei, T. Kiss, M.M. Castro, C.F. Geraldes, F. Avecilla, Chem. Eur. J. 10 (2004) 2301-2317.

[51] J. Burgess, B. Castro, C. Oliveira, M.C. Rangel, Polyhedron 16 (1997) 789-794.

[52] M.M. Castro, C.F. Geraldes, P. Gameiro, E. Ferreira, B. Castro, M. Rangel, J. Inorg. Biochem. 80 (2000) 177-179.

[53] M.M. Castro, F. Avecilla, C.F. Geraldes, B. Castro, M. Rangel, Inorg. Chim. Acta 356 (2003) 142-154.

[54] M. Rangel, A. Tamura, C. Fukushima, H. Sakurai, J. Biol. Inorg. Chem. 6 (2001) 128-132.

[55] A. Rockenbauer, L. Korecz, Appl. Magn. Reson. 10 (1996) 29-34.

[56] N.D. Chasteen, in: J. Lawrence, L. Berliner, J. Reuben (Eds.), Biological Magnetic Resonance, Vol. 3, Plenum Press, New York, 1981, pp. 53-119.

[57] L. Casella, M. Gullotti, A. Pintar, S. Colonna, A. Manfredi, Inorg. Chim. Acta 144 (1988) 89-97.

[58] A.J. Tasiopoulos, A.N. Troganis, A.M. Evangelou, C. Raptopoulou, A. Terzis, Y. Deligiannakis, T.A. Kabanos, Chem. Eur. J. 5 (1999) 910-921.

[59] T.S. Smith 2nd, C. Root, J. Kampf, P. Rasmussen, V.L. Pecoraro, J. Am. Chem. Soc. 122 (2000) 767-775.

[60] E.J. Tolis, V.I. Teberekidis, C.P. Raptopoulou, A. Terzis, M.P. Sigalas, Y. Deligiannakis, T.A. Kabanos, Chem. Eur. J. 12 (2001) 2698-2771.

[61] T.S. Smith 2nd, R. LoBrutto, V.L. Pecoraro, Coord. Chem. Rev. 228 (2002) $1-18$

[62] T.C. Delgado, M.M. Castro, C.F. Geraldes, J.G. Jones, Magn. Reson. Med. 51 (2004) 1283-1286.

[63] J. Mitchell (Ed.), Clinical and Diagnosis Management by Laboratory Methods, W.B. Saunders Company, Tokyo, 1991.

[64] D.C. Crans, C. Rihtner, L.A. Theisen, J. Am. Chem. Soc. 112 (1990) 2901-2908.

[65] L.H. Davis, S.E. Lux, V. Bennett, J. Biol. Chem. 264 (1989) $9665-$ 9672.

[66] I.G. Macara, G.C. McLeod, K. Kustin, Biochem. J. 181 (1979) 457465.

[67] A. Heinz, K.A. Rubinson, J.J. Grantham, J. Lab. Clin. Med. 100 (1982) 593-612.

[68] P. Buglyó, T. Kiss, E. Kiss, D. Sanna, E. Garribba, G. Micera, J. Chem. Soc. Dalton Trans. (2002) 2275-2282.

[69] T. Kiss, E. Kiss, G. Micera, D. Sanna, Inorg. Chim. Acta 283 (1998) 202-210.

[70] T. Kiss, E. Kiss, E. Garribba, H. Sakurai, J. Inorg. Biochem. 80 (2000) 65-73.

[71] G. Wilkinson, R.D. Gillard, J.A. McCleverty (Eds.), Comprehensive Coordination Chemistry, Pergamon Press, Oxford, 1987.

[72] M.C. Schrader, C.J. Eskey, V. Simplaceanu, C. Ho, Biochim. Biophys. Acta 1182 (1993) 162-178.

[73] R.B. Passey, R.L. Gillum, J.B. Fuller, R.M. Urry, M.L. Giles, Clin. Chem. 23 (1977) 131-139.

[74] M. Weismann, B. Klein, Clin. Chem. 4 (1958) 420.

[75] M. Nakai, W. Watanabe, C. Fujiwara, H. Kakegawa, T. Satoh, J. Takada, R. Matsushita, H. Sakurai, Biol. Pharm. Bull. 18 (1995) 719 725. 